Revista de Estudios Histórico-Jurídicos

[Sección historia del derecho europeo]

XL (Valparaíso, Chile, 2018)

[pp. 237 - 266]

\title{
DA POLÍCIA DOS BENS NACIONAIS DE USO GERAL E COMUM: LICENCIAMENTO, SERVIDÕES E RESTRIÇÕES IMPOSTAS À PROPRIEDADE PARTICULAR PARA UTILIDADE PÚBLICA EM PORTUGAL DE OITOCENTOS*
}

[The Police Division for National Assets of General and Common Use: Licensing, Easements and Restrictions to Private Property in the Public Interest in 19th Century Portugal]

\author{
Sandra M. G. PINTO** \\ Universidade Nova de Lisboa, Portugal
}

\begin{abstract}
RESUMEN
El presente artículo analiza la policía de los bienes nacionales de uso general y común en Portugal en el siglo XIX, mostrando sus reflejos en la propiedad particular contigua. El análisis se centra en el licenciamiento de obras particulares y las correspondientes exigencias burocráticas, pero también en la creación de las servidumbres y restricciones impuestas a la libertad de edificación privada por interés de utilidad pública.

Palabras Clave

Policía-Bienes nacionales - Propiedad particular-Licenciamiento-Servidumbres y restricciones para utilidad pública Portugal - Siglo XIX.
\end{abstract}

\begin{abstract}
This article examines the 19th Century police division for national assets in Portugal by showing the way it echoed in the neighboring private property. The analysis focuses on the granting of licenses for private works and the consequent bureaucratic requirements, but also on the creation of easements and restrictions regarding the freedom of private construction in the interest of the public construction.

KEYWORDS
Police - National assets - Private
property - Licensing - Easements and
restrictions in the public interest - Portugal
- 19th Century.
\end{abstract}

RECibido el 7 de julio de 2017 y aCEPTADO el 10 de julio de 2018

* Trabalho inserido no projeto de pós-doutoramento da autora financiado pela Fundação para a Ciência e Tecnologia (SFRH/BPD/84349/2012).

** Investigadora integrada no CHAM - Centro de Humanidades, Faculdade de Ciências Sociais e Humanas da Universidade NOVA de Lisboa e Universidade dos Açores. Direção postal: Avenida de Berna, 26-C, 1969-061, Lisboa, Portugal. Correio eletrónico: sandramgpinto@gmail.com. 
A Superintendencia das propriedades publicas consiste nos actos de conservação das mesmas [...]. A Lei administrativa não considera a propriedade particular como posse, ou transmissão, mas considera-a em suas relaçôes com o uso e emprego de interesse geral: por isso regula ella as modificaçôes dos principios geraes do direito civil; e determina a aç̧ão publica a respeito da propriedade particular [...].

José Xavier Mouzinho da Silveira $(1832)^{1}$

\section{DAS COMPETÊNCIAS SOBRE OS BENS NACIONAIS}

Nas primeiras décadas do século XIX, operou-se no reino de Portugal uma profunda reforma das instituiçôes políticas e administrativas, assente na separação dos poderes públicos e em direitos individuais, dando origem ao Estado Liberal ${ }^{2}$. A nova administração pública, inspirada no modelo napoleónico e entendida como uma "cadêa, que liga todas as partes do corpo social, e forma dellas um todo", a ter diversos níveis de poder, hierarquicamente subordinados, estando no topo o governo do Estado ${ }^{4}$. Esta reforma afetou seriamente a autonomia das câmaras municipais na gestão econômica dos respetivos territórios. Se estas entidades se mantiveram como corpo administrativo dos concelhos, foram-lhes, porém, retiradas as seculares funçôes judiciais, fiscais e executivas. A uma fase inicial (entre 1832 e 1834) em que as câmaras municipais apenas ficaram responsáveis por funções deliberativas e consultivas -não deixando, evidentemente, de reagir e reclamar o restabelecimento das suas antigas jurisdiçôes ${ }^{5}$-, seguiu-se uma outra fase em que viram alargadas as suas competências administrativas e policiais ${ }^{6}$.

${ }^{1}$ Relatório prévio às reformas da fazenda, da justiça e da administração. Collecção de Decretos e Regulamentos mandados publicar por Sua Magestade Imperial o Regente do Reino desde que assumiu a regencia em 3 de Março de 1832 até á sua entrada em Lisboa em 28 de Julho de 1833 (Lisboa, 1836), p. 70.

${ }^{2}$ Entre outros, Hespanha, António M., Guiando a mão invisivel. Direitos, Estado e Lei no Liberalismo Monárquico Português (Coimbra, 2004).

${ }^{3}$ Ver nota 1, p. 62.

${ }^{4}$ A reforma da administração pública foi definida pelo decreto n. ${ }^{\circ} 23$ de 16 de maio de 1832, estabelecendo quer as bases de divisão territorial administrativa (regulada pelo decreto n. ${ }^{\circ} 65$ de 28 de junho de 1833), quer as competências dos respetivos órgãos de poder. Colleç̧ão de Decretos, cit. (n. 1), pp. 87-101, 329-341. Esclareça-se, contudo, que o Reino de Portugal, e Algarves, tal como foi definido na Carta Constitucional de 1826 (depois da independência do Brasil), compreendia territórios na Europa (a parte continental -isto é, a zona ocidental da península Ibérica-, e as ilhas adjacentes da Madeira e Porto Santo e arquipélago dos Açores), mas também na Africa e na Ásia. Carta Constitucional da Monarchia Portugueza (Lisboa, 1826), art. 2, p. 4. Porém, neste estudo focam-se apenas as medidas estabelecidas para o primeiro daqueles territórios, não só por este ter sido o território de origem e ser ainda o atual espaço físico português, mas porque os territórios ultramarinos (também chamados de coloniais) tiveram uma organização administrativa diferenciada regulada por leis específicas.

5 Manique, António Pedro, Poder municipal ou poder administrativo? Um conflito entre a Câmara Municipal de Lisboa e o Governo (1834-1835), em Cadernos do Arquivo Municipal (Lisboa), 2 (2014), pp. 243-269.

${ }^{6}$ Pela carta de lei de 25 de abril de 1835 revogou-se a reforma administrativa de 1832 , 
Dentro dessas atribuições camarárias cabia a secular faculdade de proteger os bens públicos e os espaços de circulação viária dos concelhos ${ }^{7}$. Afinal, a própria Constituição Portuguesa de 1822 tinha reconhecido que lhes pertencia "Tratar das obras particulares do concelhos e do reparo das publicas; e promover a plantação

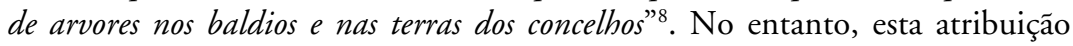
constitucional esteve para ficar definida com maior amplitude, pois o artigo proposto referia que as câmaras deveriam "cuidar na construção, e reparo das estradas, calçadas, pontes, encanamento de rios, plantação de arvores nos baldios, e terras do concelho, e geralmente em todas as obras de publica necessidade, utilidade, ou ornato". Porém, durante discussão do Projeto da Constituição Politica, esta cláusula foi bastante simplificada por haver dúvidas sobre a justa incumbência das câmaras nas obras públicas gerais (como estradas reais ou encanamentos de rios), já que por serem de todos, as tarefas de construção e reparação deveriam recair sobre o governo. Dúvidas, que se estendiam ainda às questóes: se às câmaras competia

sendo o novo sistema regulamentado pelos decretos de 18 de julho e de 12 de setembro de 1835 (com parcas alteraçóes introduzidas pela carta de lei de 28 de março e pelo decreto de 6 de novembro de 1836), dando origem ao sistema administrativo contemporâneo português, assente em três entidades: os distritos compostos por concelhos compostos por freguesias. Assim, acima do concelho existia apenas um único grau de administração, o distrito, braço local do poder central. Por decreto de 31 de dezembro de 1836 foi aprovado o primeiro Código Administrativo Português, que na essência manteve a estrutura anterior. Collecção de Leis e outros Documentos Officiaes Publicados, Agosto de 1834-1840 (Lisboa, 1837-1840), ano de 1835, pp. 132-133, 194-222, 317-319; ano de 1836 (1 ${ }^{\circ}$ sem.), pp. 50 e (2o sem.), pp. 112-113; ano de 1837 (1ºm.), p. 22; e Codigo Administrativo Portuguez (Lisboa, 1837). Ver ainda: CAETANO, Marcelo, A codificação administrativa em Portugal (um século de experiência 1836-1935), em Revista da Faculdade de Direito da Universidade de Lisboa, 2 (1934), pp. 324-405; MANIQUE, António Pedro, Liberalismo e Instituiçōes Municipais, 1822-1910, em 2. ${ }^{\circ}$ Encontro Nacional de Arquivos Municipais (Montemor-o-Novo, 23-25 de Novembro de 1988), Actas (Lisboa, 1992), pp. 79-86; e SiLVEIRA, Luís Nuno Espinha, Território e poder: nas origens do estado contemporâneo em Portugal (Cascais, 1997), pp. 76-105.

${ }^{7}$ Nas Ordenaçôes Afonsinas, de 1446, aos vereadores das câmaras municipais competia "Saber como os caminhos, fontes, e chafarizes, pontes, e calçadas, e muros, e barreiras som repairados, e os que cumprir de se fazer, e adubar, e correger, mandalas fazer, e repairar; e abrir os caminhos, e testadas em tal guisa, que possam bem servir per elles". Ordenaçōes Afonsinas (5 vol.s, fac-símile da ed. de 1792, Lisboa, 1984), I, Tít. XXVII, $\$$ 6, p. 174; disposição mantida nas compilações legislativas seguintes, de 1521 e 1603: Ordenaçōes Manuelinas (5 vol.s, fac-símile da ed. de 1797, Lisboa, 1984), I, Tít. XLVI, $\$ 5$, p. 324 e Ordenaçōes e Leis do Reino de Portugal, publicadas em 1603 (5 vol.s, Coimbra, 1789-1790), I, Tít. LXVI, \$24, p. 304 . O Código Administrativo de 1836 definia como atribuição das câmaras municipais: "Emprehender quaisquer Obras novas por conta do Concelho, taes como a feitura de caminhos, estradas, construcção de Pontes, calçadas, fontes etc. do uso comum dos moradores, e por elles pagas; ou alterar essencialmente alguma já existente". Código Administrativo, cit. (n. 6), p. 28. Por portaria de 26 de setembro de 1839, invocava-se "tanto pela Legislação antiga, como pela moderna" a obrigação das câmaras construírem e repararem os caminhos, estradas, pontes e calçadas dos respetivos municípios, nem consentir que fossem obstruídos, embaraçados ou estreitados, não só porque "seria isso uma usurpação da propriedade do uso comum dos Povos, mas tambem por a demasiada circumscripção dos limites marginaes dos mesmos caminhos é mais um estorvo para o cómmodo transito e transporte". Collecção de Leis, cit. (n. 6), ano de 1839, pp. 389-390.

${ }^{8}$ Constituição Politica da Monarchia Portugueza (Lisboa, 1822), art. 233. ${ }^{\circ}$, n.o V, p. 83. 
a construção ou apenas a conservação, e, se teriam meios económicos e técnicos para as empreenderem. No fim, e de modo a não ampliar os anteriores poderes camarários, mas também porque, em rigor, este não era um artigo constitucional", pois, "o que he constitucional he que as camaras cuidem nas atribuiçôes proprias dos concelhos", apenas ficaram confirmadas as faculdades e funções que as câmaras sempre tiveram nesta matéria ${ }^{10}$.

Não obstante, o alvará de 14 de janeiro de 1826 veio a atestar e a regular a incumbência das câmaras municipais em vigiar e cuidar na conservação as obras públicas gerais, ainda que debaixo da inspeção, fiscalização e responsabilidade da Intendência-Geral das Obras Públicas ${ }^{11}$. Ora, parte da proteção que as câmaras municipais exerciam sobre os bens públicos assentava no controlo preventivo e de polícia, exigindo que os particulares, antes de iniciarem a edificação de uma obra localizada à face dos espaços públicos de circulação viária, solicitassem a devida licença de obras ${ }^{12}$-que incluía a marcação do alinhamento do edifício efetuado pelas autoridades camarárias- e, desde a portaria de 6 de junho de 1838, fazer depender a própria licença da "approvação pela Camara da respectiva planta, comminando aos contraventores as necessarias multas, e a demolição da obra feita sem approvação da planta, ou contra a planta approvada"13.

Contudo, em 21 de dezembro de 1840, as câmaras municiais dos concelhos confinantes com o rio Douro ficaram inibidas de concederem as licenças aos par-

9 Por isso, no texto das constituições seguintes, de 1826 e de 1838, desaparece a especificação das atribuições camarárias, remetendo-se o exercício das funções municipais para a lei regulamentar. Carta Constitucional, cit. (n. 4), art. 135.', p. 48; e Constituição Politica da Monarchia Portugueza (Lisboa, 1838), art. $130 .^{\circ}$ e $131 .^{\circ}$, p. 24.

10 Diario das Cortes Geraes e Extraordinarias da Nação Portugueza - Segundo anno da legislatura (Lisboa, 1822), pp. 17 (art. 200. ${ }^{\circ}$, n. ${ }^{\circ}$ IV), 465-467. Ver também HespanHA, António M., cit. (n. 2), pp. 104-105.

11 Collecção de todas as leis, alvarás, decretos etc impressos na regia officina tipográfica, 18241828 (Lisboa/Porto, 1843-1845), ano 1826, pp. 5-9. A Intendência-Geral das Obras Públicas teve origem na Repartição das Obras Públicas da Junta do Comércio, criada para atender ao processo de reconstrução da cidade de Lisboa após o terramoto de 1755, transformando-se no final do século XVIII num serviço central de obras públicas. MoNTEIRO, Cláudio, Escrever direito por linhas rectas, Legislação e planeamento urbanístico na Baixa de Lisboa (1755-1833) (Lisboa, 2010), pp. 198-203. No segundo quartel do século XIX foi reorganizada a estrutura administrativa responsável pela gestão das obras públicas a cargo do governo: a 4 de maio de 1836 a Intendência (também chamada de Repartição) passou a contar com três divisões (obras públicas, estradas e palácios) e em 18 de junho do mesmo ano foram constituídas três divisões territoriais (Norte, Centro e Sul) para o fim das obras públicas e decidir sobre reparos, abertura e construção das estradas, canais, pontes, portos e barras dos rios. Todas estas entidades encontravam-se subordinadas ao Ministério dos Negócios do Reino. Collecção de Leis, cit. (n. 6), ano de 1836 (1ํ sem.), pp. 89, 168-169. Ver também Matos, Artur Teodoro, Transportes e comunicaçōes em Portugal, Açores e Madeira (1750-1850), (Ponta Delgada, 1980), p. 197.

${ }_{12}$ Este controlo começou a ser regulado em Portugal no início do século XVI. Ver PINTO, Sandra M. G., A regulação jurídica das fachadas em Portugal (séc. XIV-XIX), em REHJ., 38 (2016), pp. 160-177.

${ }_{13}$ Collecção de Leis, cit. (n. 6), ano de 1838, p. 262. Esta planta era na verdade o projeto da fachada, ou de acordo com a terminologia da época, o prospeto do edifício. PINTO, Sandra M. G., cit. (n. 12), pp. 168-170. 
ticulares que pretendessem edificar ou fazer quaisquer outras obras nos terrenos marginais deste rio ${ }^{14}$. A razão assentava em dois fatores: por um lado a propriedade daqueles terrenos não era municipal e, por isso, as câmaras não podiam dispor sobre eles; por outro, as concessões que indevidamente eram autorizadas pelas câmaras provocavam graves prejuízos à navegação do rio e ao melhoramento e bom estado da própria barra. Daí que o poder central estabeleceu, por decreto, que a administração dos terrenos marginais ao rio Douro, "por serem propriedade publica”, ficava a cargo dos administradores-gerais dos distritos respetivos. Já a concessão das licenças de edificação e/ou de outras obras naquelas áreas passava a ser uma incumbência do governo, sendo expedida pela Secretaria de Estado (também chamada de Ministério) dos Negócios do Reino, precedida da informação do administrador-geral do distrito e ouvidas igualmente a entidade do governo responsável pelas obras da barra (a recém-criada Inspeção-Geral das Obras Públicas $^{15}$ ), bem como, a respetiva câmara municipal ${ }^{16}$.

A solicitação ao governo para autorizar as construções nas margens dos rios tornava-se, então, obrigatória mesmo quando as obras a intentar eram de interesse público local e promovidas pelas câmaras municipais. Isto se percebe pela portaria de 5 de julho de 1848, pela qual se mandava comunicar ao governador civil de Lisboa que, sendo os rios propriedade pública, só o governo podia autorizar obras nas suas margens, indo, assim, contra a autorização dada pela câmara municipal de Setúbal sobre a construção de uma ponte de madeira para prolongamento do cais da vila ${ }^{17}$.

Saliente-se, contudo, que esta medida, sobre um objeto que não estava devidamente regulamentado, não pode ser ainda considerada como uma tentativa de centralização pelo governo de certas competências das câmaras municipais, tal como aquelas que nos anos seguintes acabaram por reforçar a influência do poder central sobre a ação do poder local, fosse por via da fiscalização da sua administração ${ }^{18}$, fosse pelo aumento do peso da tutela e pela ingerência desta nas

${ }^{14}$ Estas ações camarárias encontravam sustentação na tradição, mas também, porque, por portaria de 16 de dezembro 1837, as câmaras municipais dos concelhos situados nas margens do rio Douro obtiveram a incumbência para fiscalizar e regular nas suas posturas a proibição dos particulares lançarem entulhos no rio, para não entupir e dificultar a navegação fluvial. Collecção de Leis, cit. (n. 6), ano de 1837 (2º sem.), pp. 241.

${ }^{15}$ A Inspeção-Geral das Obras Públicas foi criada pelo decreto de 7 de março de 1840 , tendo o conselheiro Luís da Silva Mouzinho de Albuquerque, por portaria de 9 de maio seguinte, ficado encarregue de a organizar. Collecção de Leis, cit. (n. 6), ano de 1840, p. 72.

16 Collecção Official de Legislação Portuguesa, 1841-1910 (Lisboa, 1842-1911), ano de 1844, p. 427 (em nota). Porém, a câmara municipal do Porto, em 6 de dezembro de 1848 e 12 de junho de 1856, questionou os órgãos governativos sobre como se deveria entender por "terrenos marginaes do Douro". Em 9 de outubro de 1861, o Conselho das Obras Públicas, pelo parecer do diretor das Obras Públicas do distrito do Porto, afirmou que aqueles terrenos marginais eram entendidos como "uma facha de terreno com largura de quinze metros, alem das maiores aguas nos leitos de maré. Largura que póde e tem de modificar-se n'alguns casos”. Boletim do Ministerio das Obras Publicas, Commercio e Industria (Lisboa, 1853-1868), ano 1862 (1, jan.), pp. 45-47.

17 Collecção Official, cit. (n. 16), ano de 1848, pp. 93-94.

18 Caso da carta de lei 29 de outubro de 1840 que submetia a aprovação das posturas e regulamentos municipais ao conselho de distrito e criava os conselhos municipais (regulados 
decisões camarárias ${ }^{19}$. É que em rigor, e desde o tempo das Ordenações Afonsinas, as "Estradas, e ruas pruvicas antiguamente usadas, e os Rios navegantes, e aquelles, de que se fazem os navegantes, se som cabedaaes, que correm continuadamente em todo tempo" pertenciam ao património régio, não obstante "o uso assy das estradas, e ruas pruvicas, como dos Rios seja igualmente comuu[n] a toda gente, e a qualquer outra cousa animada" ${ }^{20}$. Ora, pelo decreto de 5 de maio de 1821 todo este património tinha já passado para o Estado com a designação de "Bens Nacionaes"21.

\section{Da centralização administrativa e do licenciamento das obras particulares}

A uma ordem dominial e territorialmente circunscrita seguiu-se uma outra geral, para a qual, com certeza, tinha contribuído a recente reclassificação, hierarquização e programação feita para as vias terrestres de circulação do reino ${ }^{22}$. Seguindo o espírito sistematizador oitocentista, estas vias passaram a estar divididas em estradas, a cargo do governo, e caminhos, a cargo dos municípios ${ }^{23}$.

pela lei de 16 de outubro de 1841), órgão que em conjunto com a câmara discutia e aprovava a gestão financeira do município. Collecção de Leis, cit. (n. 6), ano de 1840, pp. 62-68; ano de 1841, p. 245.

19 Alterações estabelecidas no novo Código Administrativo, aprovado pelo decreto de 18 de março de 1842. Codigo Administrativo (Lisboa, 1842). Saliente-se que ao nível divisão territorial, este Código conservou o anterior sistema de distritos, concelhos e freguesias, acrescentando ainda que os concelhos de Lisboa e Porto eram subdivididos em bairros. Ao nível da organização administrativa, o distrito era administrado pelo governador civil tendo como corpo administrativo a junta geral, havendo ainda um conselho de distrito responsável pelo contencioso. O magistrado do concelho era o administrador de concelho, tendo como corpo administrativo a câmara municipal, havendo ainda um conselho municipal. O bairro tinha também um magistrado chamado de administrador do bairro. O Código Administrativo de 1842, bastante centralizador, esteve em vigor até 1878, com exceção do período em que vigorou a Lei da Administração Civil, aprovada em 26 de junho de 1867 e revogada em 14 de janeiro de 1868 . Em 1878 entrou em vigor um novo Código Administrativo, mais descentralizador, sendo substituído pelo Código de 1886 e este pelo de 1895, logo substituído pelo de 1896, um dos mais centralizadores e que se manteve em vigor até à instauração do regime republicano. Ver CAETANO, Marcelo, cit. (n. 6), pp. 347-384; Manique, António Pedro, cit. (n. 6), pp. 86-88; Serra, José B., As reformas da administração local de 1872 a 1910, em Análise Social, 24/103-104 (1988), pp. 1037-1066.

20 Ordenaçōes Afonsinas, cit. (n. 7), II, Tít. XXIV, $\$$ 5, pp. 210-211; disposição mantida nas Ordenaçôes Manuelinas, cit. (n. 7), II, Tít. XV, $₫ 7$, p. 43 e nas Ordenações e Leis, cit. (n. 7), II, Tít. XXVI, $\$ 8$, pp. 47-48.

${ }^{21}$ Collecção de legislação das Cortes de 1821 a 1823 (Lisboa, 1843), pp. 27-28. Pelo decreto de 13 de agosto de 1832, esclarecia-se que "Os Bens da Nação, tomada collectivamente, são os Bens do uso geral, e commum dos habitantes, como Pórtos, Canaes, Rios navegaveis, Estradas geraes, e Pontes nellas construidas, Caes, e Edificios destinados para a residência do Rei, ou para as Sessöes das Camaras, Secretarias, Tribunais, Aquartelamentos, Estaleiros, Arsenaes, e outros semelhantes". Collecção de Decretos, cit. (n. 1), pp. 216-218.

22 Já antes, com a criação em 1835 da Comissão dos Melhoramentos de Comunicação Interior (responsável por levantar um plano geral e propor medidas de melhoramento das vias de comunicação, terrestres e fluviais, do reino), as estradas a cargo do governo tinham ficado divididas em três classes. Collecção de Leis, cit. (n. 6), ano de 1835 (10 sem.), pp. 84-85.

${ }^{23}$ Lei de 22 de julho de 1850. Collecção Official, cit. (n. 16), ano de 1850, pp. 440-446. As estradas foram ainda subdivididas em dois tipos: de primeira classe e segunda classe, diferenciando-se não apenas na importância do seu trajeto (as primeiras eram as que conduziam a 
Assim, em 21 de agosto de 1850, uma portaria-circular estabeleceu que todos os administradores dos concelhos e câmaras municipais passavam a estar proibidos de concederem licenças para construçôes particulares que se localizassem no " $\mathrm{do-}$ minio geral da nação, assim as estradas, e nas margens dos rios, e vallas reaes, como os edificios publicos". Sendo esta ordem expedida a todos os governadores civis de todos os distritos, ela fazia-se aplicar a todo o reino, quer no continente, quer nas ilhas adjacentes.

Tal como acontecia com o decreto de 1840, a medida tentava evitar os "gravissimos prejuizos" que atingiam quer a segurança individual, quer o interesse público, porque as licenças que as câmaras municipais permitiam ou toleravam não eram "precedidas dos competentes exames technicos", nem dos "respectivos projectos examinados e aprovados por pessoas competentemente habilitadas por seus conhecimentos especiaes". Desta forma, o governo chamava a si a competência de "julgar da conveniencia ou desvantagem, com que devam ser permittidas construcçôes particulares junto a essas propriedades nacionaes”, cuja licença passava a ser requerida por via do Ministério dos Negócios do Reino ${ }^{24}$.

Contudo, introduzir uma nova entidade na concessão das licenças contra a secular prática municipal não se revelou tarefa fácil, nem imediata. Em poucos anos o governo teve de remeter nova ordem para todos os distritos, devido aos abusos cometidos ${ }^{25}$; esclarecer o governador civil de Lisboa que as licenças relativas a obras particulares na proximidade das estradas a cargo do poder central eram as classificadas como de primeira ou segunda classe, ficando a cargo das respetivas câmaras municipais "a concessão de licenças para se effectuarem obras junto aos caminhos municipaes e vicinaes" ${ }^{26}$; e reenviar novamente a mesma ordem a todos os distritos de modo a exigir o seu cumprimento, pois "por ignorancia d'aquella ordem, ou por descuido na sua execução por parte de algumas Auctoridades administrativas, têem estas e as Camaras Municipaes frequentemente concedido licenças para edificaçōes, que depois são embargadas pelos Delegados das Obras Publicas", mandando igualmente que a determinação fosse afixada nos concelhos com o fim de se lhe dar maior publicidade, especialmente para os particulares ${ }^{27}$. Os referidos delegados, que mandavam embargar as obras em contravenção, eram os funcionários distritais da Inspeção-Geral das Obras Públicas, os quais, desde 1844, ficaram incumbidos

capital do reino às capitais de distrito e aos pontos importantes do reino vizinho, enquanto as segundas eram as que ligavam as capitais de distrito entre si e com as cidades e vilas importantes e aquelas que destes pontos convergiam às estradas da primeira classe, aos portos secos ou aos portos marítimos), como também na sua largura (36 palmos (7,92 metros) para as primeiras, contra 30 palmos (6,6 metros) para as segundas). Também os caminhos foram subdivididos em dois: caminhos municipais e caminhos vicinais, cujos primeiros ligavam as povoaçôes mais importantes dentro de um concelho ou com os concelhos limítrofes ou ainda com as estradas, e os segundos eram os restantes.

${ }^{24}$ Collecção Official, cit. (n. 16), ano de 1850, p. 761.

${ }^{25}$ Portaria-circular de 3 de janeiro de 1852. Collecção Official, cit. (n. 16), ano de 1852, p. 1.

${ }^{26}$ Portaria de 5 de setembro de 1853. Colleç̧ão Official, cit. (n. 16), ano de 1853, pp. 465-466.

27 Portaria-circular de 30 de maio de 1857. Collecção Official, cit. (n. 16), ano de 1857, pp. 127-128. 
de dar apoio às câmaras municipais para a direção dos trabalhos públicos a cargo dos municípios, devido à falta de empregados competentes nas estruturas locais ${ }^{28}$.

No seguimento da criação e organização do Ministério das Obras Públicas, Comércio e Indústria (fragmentado ao Ministério dos Negócios do Reino) em $1852^{29}$-sendo, aliás, a construção e manutenção das vias de circulação uma das principais reformas a implementar pelo novo ministério ${ }^{30}$, a competência para fiscalizar as obras públicas e auxiliar as câmaras municipais passou a ser devida aos diretores distritais das Obras Publicas ${ }^{31}$. Por esta altura, foi ainda criada uma repartição específica, consagrada apenas para as obras em andamento na cidade e distrito de Lisboa, chamada de Intendência das Obras Públicas do Distrito de Lisboa (extinguindo-se com esta a Inspeção-Geral das Obras Públicas). Esta Intendência ficava também responsável, em conjunto com a câmara municipal, pelo exame, aprovação e fiscalização dos projetos de obras particulares na cidade, procurando que estas obras não incomodassem o público, satisfizessem os preceitos da arte das construçóes e estivessem em harmonia com os melhoramentos projetados pelo governo ${ }^{32}$.

Mas só em 1859 é que se estabeleceu o serviço regular das Inspeções de Obras Públicas distritais, dividindo-se, para o efeito, o reino provisoriamente em cinco inspeções, reduzidas a três em $1868^{33}$. Porém, entre o muito trabalho que estas inspeções tinham com a verificação do bom andamento dos trabalhos públicos, competia-lhes ainda a verificação das "obras marginaes [às vias fluviais, valas e canais] em construcção se foram competentemente auctorizadas, se são vantajosas ou prejudiciais, se são construidas com conhecimento da auctoridade" 34 .

Em 15 de julho de 1862 foi de novo reorganizada a classificação das vias terrestres de circulação, passando a haver três tipos: as estradas de primeira ordem ou

${ }^{28}$ Portaria de 8 de maio de 1844. Collecção Official, cit. (n. 16), ano de 1844, p. 82. Com efeito, também o Código Administrativo de 1842 estabeleceu que "As auctoridades superiores podem fazer cumprir por delegados especiaes as suas decisões e ordens". Codigo Administrativo, cit. (n. 19$)$, art. $355 .^{\circ}, \$ 1$, p. 83.

29 Decreto de 30 de agosto 1852 (criação do ministério) e decreto de 30 de setembro de 1852 (organização do ministério). Collecção Official, cit. (n. 16), ano de 1852, pp. 383-384 e 513-516.

${ }^{30}$ Foi através deste ministério que se promoveram as políticas de fomento económico e desenvolvimento das obras públicas com vista ao progresso e à regeneração de Portugal. Este movimento foi, por isso mesmo, chamado de Regeneração, sendo balizado entre os finais de abril de 1851 e 1890 e caracterizado por uma relativa estabilidade política, modernização das estruturas e dos meios de administração e melhoramento material. Entre outros, ver ALMEIDA, Pedro Tavares de, A construção do Estado Liberal. Elite política e burocracia na 'Regeneração' (1851-1890) (Tese de doutoramento, Universidade Nova de Lisboa, 1995), pp. 8-9.

31 Portaria-circular de 16 de dezembro de 1852. Collecção Official, cit. (n. 16), ano de 1852, p. 750.

32 Decreto de 23 de dezembro de 1852. Collecção Official, cit. (n. 16), ano de 1852, pp. 788-790.

${ }^{33}$ As cinco inspeçōes iniciais (Norte, Centro-Norte, Centro-Sul, Sul, Ilhas) ficaram reduzidas às do Norte, Sul e Ilhas. Decreto de 19 de agosto de 1859 e decreto de 6 e portaria de 11 de março de 1868. Collecção Official, cit. (n. 16), ano de 1859, p. 423; ano de 1868, pp. 73 e 75.

${ }^{34}$ Instrução do decreto de 19 de agosto de 1859. Collecção Official, cit. (n. 16), ano de 1859, pp. 423-426. 
reais; as estradas de segunda ordem ou distritais; e as estradas de terceira ordem ou municipais. As estradas de primeira e de segunda ordem podiam ainda ser divididas em estradas de primeira classe (as diretas) e de segunda classe (as transversais). A alteração da nomenclatura foi acompanhada pela distribuição das competências de construção, conservação e policia pelas diversas entidades administrativas, ficando as estradas reais a cargo do governo, as estradas distritais a cargo dos distritos e as estradas municipais a caso dos municípios (não obstante as últimas puderem vir a ser subsidiadas pelo governo $)^{35}$. Já as estradas municipais foram, dois anos depois, também divididas em duas classes, chamando-se caminhos concelhios àquelas que tinham interesse comum para mais do que um concelho, e caminhos vicinais às que tinham interesse especial para um só concelho ${ }^{36}$. Esta reorganização não alterou, contudo, a lógica estabelecida em 1850, mantendo-se o governo na competência exclusiva de licenciar as obras particulares junto as estradas reais e distritais ${ }^{37}$, mas também junto de margens dos rios, valas reais, edifícios públicos e ainda de barras, portos, praias e quaisquer outras propriedades nacionais ${ }^{38}$. Mas competia agora ao governo também a conservação e polícia das ruas que faziam parte das estradas reais ou distritais, ou seja, quando estas últimas atravessavam o interior das povoaçôes ${ }^{39}$. Somente as restantes estradas e ruas municipais, de acordo com a prática antiga, mantiveram-se na competência exclusiva dos municípios.

Todavia, em 1864, o governo, no âmbito da autorização régia que lhe permitia decretar medidas legislativas para os serviços de polícia relacionados com as infraestruturas de comunicação do país ${ }^{40}$, passou a considerar que, tal como todas as restantes estradas eram "domínio público", também as ruas no interior das povoaçôes não mais podiam ser consideradas como propriedade particular dos municípios. Esta alteração permitiu que o governo lograsse o direito de "superintender na sua construcção, conservação e policia”, embora não quisesse com isso enfraquecer "a acção municipal” ou reduzir "as atribuiçôes das camaras", afirmando que, pelo contrário, queria mantê-las e fortalecê-las através dos "auxilios technicos $e$ administrativos da auctoridade central" 41 . Assim, através do decreto com força de lei de 31 de dezembro de 1864, o governo estabeleceu um regulamento para a

35 Lei de 15 de julho de 1862. Collecção Official, cit. (n. 16), ano de 1862, pp. 207-210.

${ }^{36}$ Lei de 6 de junho de 1864. Collecção Official, cit. (n. 16), ano de 1864, pp. 223-226.

37 Conforme se encontrava expresso na portaria-circular de 3 de janeiro de 1852 (ver nota 25), na lei de 15 de julho de 1862 (ver nota 35) e no esclarecimento feito às câmaras municipais do distrito de Évora, por portaria de 18 de setembro de 1862. Collecção Official, cit. (n. 16), ano de 1862, p. 31 (supl.).

38 Portaria-circular de 31 de agosto de 1864. Colleç̧ão Official, cit. (n. 16), ano de 1864, pp. 603-604. No entanto, os abusos sobre esta matéria sucediam-se, levando o intendente das Obras Públicas do Distrito de Lisboa, por edital de 16 de outubro de 1864, a republicar a portaria-circular de 21 de agosto de 1850 (ver nota 24) e a determinar que os delegados da Intendência embargassem todas as obras que não tivessem a devida autorização dada pelo Ministério das Obras Públicas. Collecção Official, cit. (n. 16), ano de 1864, pp. 796-797.

39 De acordo com os $\$ \$ 2$ e 4 do art. 9. ${ }^{\circ}$ da lei de 15 de julho de 1862 (ver nota 35).

${ }^{40}$ Carta de lei de 25 de junho de 1864. Collecção Official, cit. (n. 16), ano de 1864, p. 319.

${ }^{41}$ Relatório prévio à publicação do decreto de 31 de dezembro de 1864 . Collecção Official, cit. (n. 16), ano de 1864, pp. 1041-1042 (em nota). 
construção, conservação e polícia de todas as estradas e demais ruas municipais, incluindo as que estivessem no interior das cidades, vilas e povoaçôes do reino ${ }^{42}$.

\section{DAS SERVIDŌES E RESTRIÇÕES PELA CONTIGUIDADE ÀS} VIAS DE COMUNICAÇÃO

No período moderno, as câmaras municipais foram criando normas reguladoras para a atividade construtiva que ocorresse nas propriedades particulares situadas à face das ruas no interior das povoaçôes ${ }^{43}$. O mesmo não acontecia com as propriedades particulares localizadas na orla das estradas, cuja construção desfrutava de uma ampla liberdade legal e formal. Ora, em 23 de julho de 1850, com a promulgação da lei geral das expropriações, definiu-se também que às propriedades particulares confinantes com os bens nacionais (estradas ou canais) podiam ser impostas servidôes por utilidade pública. Estas servidões podiam ser temporárias, quando os terrenos eram ocupados por tempo determinado (por exemplo, durante as obras de construção e conservação), ou permanentes, quando os terrenos eram afetados de forma perpétua. No último caso, definia-se que os proprietários tinham que deixar na parte confrontante com as estradas ou canais um intervalo com a largura de 1 vara $\left(1,1\right.$ metros $\left.^{44}\right)$, onde não podiam plantar árvores, nem construir obra alguma sem autorização do governo, e caso esta fosse denegada teriam direito à competente indemnização. Os proprietários ficavam também obrigados a suportar as servidōes de água ou quaisquer outras que viessem a ser impostas ${ }^{45}$.

Estas servidōes (e/ou restriçōes) por utilidade pública ${ }^{46}$, por limitarem o direito de propriedade particular, estiveram para ser reproduzidas no primeiro Código

42 Collecção Official, cit. (n. 16), ano de 1864, pp. 1041-1049.

43 Pinto, Sandra M. G., cit. (n. 12), pp. 158-163.

44 A alteração do sistema métrico em Portugal foi definida no decreto de 13 de dezembro de 1852, criando-se um prazo de 10 anos para a sua aplicação. Collecção Official, cit. (n. 16), ano de 1852, pp. 740-744.

45 Collecção Official, cit. (n. 16), ano de 1850, pp. 463-472.

46 Marcelo Caetano esclareceu que a doutrina administrativa contempla os poderes da administração sobre a propriedade privada segundo as rúbricas restriçôes de utilidade pública ao direito de propriedade e servidôes administrativas, isto é, as de utilidade pública, "não faltando quem faça figurar as duas designações uma a par da outra”. CaETano, Marcelo, Manual de Direito Administrativo (10. a ed. revista e atualizada, Coimbra, 1991), II, p. 1050. Esta confusão terminológica não era, contudo, nova, nem circunscrita ao direito administrativo, havendo-a também relativamente às relações jurídicas entre particulares definidas no direito civil, cujo tratamento conjunto de ambas começou a ser feito no Direito Justinianeu recebendo novo impulso com a obra de Bártolo de Sassoferrato (1314-1357), pela qual se estendeu no tempo. Afinal, o influente Code Civil des Français agregava toda esta matéria debaixo da categoria de servidōes. Code Civil des Français, Conforme à l'Édition originale de l'Imprimerie de la République (Toulouse, 1806), pp. 131-136. Sobre esta matéria ver, sobretudo, AmUnÁtegui Perelló, Carlos Felipe, Las relaciones de vecindad y la teoría de las inmisiones en el Código Civil, em Revista de Derecho de la Pontificia Universidad Católica de Valparaiso, 38/1 (2012), pp. 89-103; MoNTEIRO, Cláudio, $O$ domínio da cidade, A propriedade à prova no direito do urbanismo (Tese de doutoramento, Universidade de Lisboa, 2010), pp. 111-116; e PinTo, Sandra M. G., "Portugal plantou a mais duradoira de suas conquistas". Da antiga tradição jurídica para o construtivo em 
Civil Português, aparecendo mesmo no seu projeto de 1858. No entanto, tais normas acabaram por ser suprimidas pela Comissão Revisora, por considerar que ficariam mais bem enquadradas no Código Administrativo ou em regulamentos especiais $^{47}$. Em todo o caso, no Código Civil ficou definido que os particulares com propriedades marginais a correntes de água de uso comum ficavam sujeitos a todas as servidóes que os regulamentos de polícia geral pudessem impor para a conservação, desobstrução e limpeza, mas também que não podiam impedir os vizinhos, sem acesso a outras águas públicas, de aproveitar aquelas águas, estabelecendo-se, por esta, uma servidão de passagem em benefício público ${ }^{48}$.

Mas foi o referido decreto com força de lei de 31 de dezembro de 1864 que, ao nível da conservação e polícia, agravou as servidóes e as restriçôes por utilidade pública sobre o direito de propriedade particular. Daí que, para se poder plantar árvores de grande porte no limite de um terreno contíguo às vias de circulação, tornava-se agora obrigatório deixar um espaço livre, com a largura de 2 metros, caso as vias fossem estradas reais ou distritais, ou com a largura de 50 centímetros, caso as vias fossem estradas municipais. Ninguém podia fazer edifícios sobre os muros dos viadutos, nem fazer construções, alpendres, balcões, passadiços, aquedutos sobre as estradas. Destas servidōes e restriçōes já não davam direito a indemnização. As exceçóes só eram admitidas para quem tivesse obtido uma licença expressa em documento escrito pelo Ministério das Obras Públicas, Comércio e Indústria, no caso das estradas reais e distritais, ou pela câmara municipal, no caso das estradas municipais ${ }^{49}$.

Tal como já acontecia com as ruas no interior das povoaçôes, para se poder construir nas ruas que fizessem parte das estradas reais ou distritais tornava-se obrigatório que as respetivas entidades competentes marcassem previamente o alinhamento e a cota de nível dos edifícios. Todos os processos relativos à aprovação e licenciamento de obras, bem como relativos ao alinhamento e nivelamento foram inicialmente gratuitos, até que a partir de 1867, as licenças para construção, vedaçōes ou para outros fins dadas pelo Ministério das Obras Públicas, Comércio e Indústria passaram a pagar emolumentos ${ }^{50}$.

Com a mesma data do referido decreto de 1864, foram também estabelecidas normas semelhantes para a construção e exploração das vias férreas, determinandose idênticas servidôes por utilidade pública para os proprietários de terrenos confinantes com o caminho-de-ferro. Nestes, ninguém podia fazer plantações de arvoredo, edificações ou vedações sem licença do governo e sem que o fiscal do governo fixasse o alinhamento. Tal como as anteriores, também estas licenças não pagavam inicialmente emolumentos. Nos terrenos confinantes com o caminho-de-

Portugal e no Brasil: inovação e permanência em perspetiva comparada, em Anais de História de Além-Mar, 16 (2015), pp. 385-388.

${ }^{47}$ MoreIra, Guilherme Alves, As águas no Direito Civil Português, Volume II-Das servidóes das águas (Coimbra, 1922), pp. 53-54; PinTo, Sandra M. G., cit. (n. 46), p. 392.

${ }^{48}$ Codigo Civil Portuguez, Aprovado por Carta de Lei de 1 Julho de 1867 (Lisboa, 1867), art. 381. ${ }^{\circ}$ e 440. ${ }^{\circ}$, pp. 71-72, 83-84. Ver ainda MoreIRA, Guilherme Alves, cit. (n. 47), pp. 47-50.

49 Ver nota 42.

${ }^{50}$ Lei de 16 de junho de 1867. Collecção Official, cit. (n. 16), ano de 1867, pp. 85-88. 
ferro, a plantação de árvores e as construções estava vedada numa "zona prohibida", definida em 2 metros medidos a partir de 1,5 metros da aresta exterior dos carris externos. Se tal disposição não fosse cumprida, os agentes do governo procediam ao abate das árvores e à demolição das construções. Mas, se os proprietários plantassem ou construíssem exatamente no limite mínimo imposto apenas lhes era exigido o pagamento de coima. Já para as plantações e construções que ficassem além do alinhamento legal não era necessário obter licença do governo. Porém, nestes, havia outras restrições estabelecidas para evitar a propagação de incêndios provocados pela passagem dos comboios: a menos de 20 metros não podia haver barracas de colmo, medas de palha ou feno e depósito de matérias inflamáveis; e a menos de 5 metros não podia haver depósitos de objetos não inflamáveis ${ }^{51}$.

\section{Da complexificação e multiplicação dos procedimentos burocráticos}

Dezoito anos depois de o governo ter chamado a si o licenciamento de obras particulares confinantes com as estradas reais e distritais, foram finalmente regulados os procedimentos administrativos que os particulares tinham de cumprir para solicitar a licença de construção $0^{52}$. O interessado fazia um requerimento que seria entregue na Direção distrital das Obras Públicas, o qual seria remetido pelo respetivo diretor para o governo com uma informação sobre a justiça e conveniência do pedido e com as condições e cláusulas que a licença poderia ser concedida. $\mathrm{Na}$ repartição do governo, os requerimentos e informaçôes enviadas eram processados sem envolver os respetivos proprietários. A concessão ou denegação das licenças era oficialmente comunicada aos diretores distritais das Obras Públicas, e se aceite era expedida por diploma com a nota dos emolumentos. Os diretores distritais avisavam, então, os proprietários da decisão, passando-lhes a guia para pagarem os emolumentos. Com a prova do pagamento, os proprietários recebiam o diploma, ação que tinha de ser participada ao governo.

Mas se os proprietários particulares fossem expropriados por causa da construção das estradas e que por esta causa fossem forçados a fazer obras de vedação nos seus prédios, então, não eram obrigados a requerer licença, bastando comunicar a ação ao respetivo diretor distrital das Obras Públicas. Com esta comunicação os diretores verificavam por vistoria a necessidade da obra e as suas condições, autorizando-a de modo que não houvesse prejuízo nem para o proprietário, nem para o traçado e conservação da estrada. Se neste caso não era exigido o procedimento formal do licenciamento, havia contudo a necessidade de pagar os emolumentos, que também revertiam para o cofre do Ministério.

Obviamente competia ainda aos diretores distritais das Obras Públicas a fiscalização das construções que fossem feitas por licença do governo ou por sua autorização. Por isso, no mesmo ano de 1868, foi criada em cada distrito administrativo do continente e das ilhas adjacentes uma Repartição de Obras Públicas, subordinada ao governador civil, com pessoal técnico habilitado para projetar e dirigir todas as obras públicas dos distritos e municípios respetivos, mas também

51 Decreto de 31 de dezembro de 1864. Collecção Official, cit. (n. 16), ano de 1864, pp. 1032-1038.

52 Portaria de 26 de maio de 1868. Collecção Official, cit. (n. 16), ano de 1868, p. 216. 
para o desempenho de outras funções que requeressem "conhecimentos especiaes", como era o caso da marcação do alinhamento e das cotas de nível das obras dos particulares ${ }^{53}$.

Em dezembro de 1879 , e tendo em vista simplificar o serviço dentro do Ministério das Obras Públicas, Comércio e Indústria, a concessão das licenças para plantaçōes de arvoredo, edificações e vedaçōes e outras obras particulares de qualquer natureza junto das estradas reais ou distritais, de caminho-de-ferro e nas margens dos rios foi delegada no diretor-geral das Obras Públicas ${ }^{54}$, seguindo-se novas determinações legais definidas pela portaria de 13 de dezembro do mesmo ano. A licença só podia ser concedida a quem demonstrasse ser proprietário ou pelo menos ter a posse presumida da propriedade em causa. A licença para plantação de árvores nas orlas das estradas seria concedida com a declaração de que não haveria direito de propriedade nessas árvores, nem indemnização, caso viessem depois a ser arrancadas por ordem do governo para melhoramento das vias. A licença para a edificação respeitava apenas a um só prédio, mesmo no caso em que se pretendessem edificar prédios contíguos (ou geminados), devendo-se solicitar uma licença especial. Mas, uma só licença podia ser considera conjuntamente a edificação de casa e a vedação do terreno contíguo para logradouro ou a vedação de uma propriedade sobre os dois lados de uma estrada que a tivesse atravessado. Porém, os pedidos eram agora acompanhados de planta-isto é, a planta geral, do terreno ou de localização- com a posição relativa de cada obra ${ }^{55}$.

Os diretores distritais das Obras Públicas continuavam com a incumbência de dar licença para as vedações sobre estradas públicas, podendo agora também aprovar, sem dependência do Ministério das Obras Públicas, Comércio e Indústria, o alinhamento para a reconstrução das frontarias das casas que tivessem sido expropriadas para efeito de alargamento das estradas. As licenças autorizadas pelo governo para a plantação de arvoredo e edificação junto às estradas reais, distritais, e nas ruas de povoaçôes pertencentes às estradas, eram enviadas aos diretores distritais das Obras Públicas, enquanto se fosse junto às linhas férreas eram enviadas ao diretor do caminho-de-ferro, quando as linhas eram exploradas pelo governo, ou ao diretor da fiscalização das linhas férreas, quando as linhas eram exploradas por empresas particulares. Com a receção destas licenças o funcionário de cada serviço registava-a na sua repartição e à vista da planta respetiva mandava marcar no terreno a distância a que a obra ou a plantação devia ficar da estrada ou da linha do caminho-de-ferro. Os respetivos diretores determinavam o alinhamento e o nivelamento das construçôes, sendo estas marcações definidas em conjunto com as câmaras municipais quando os prédios tinham uma frente para a propriedade pública a cargo do governo e outra frente para estrada municipal ou rua de povoação. Finalmente, a aprovação do projeto das fachadas dependia exclusivamente das câmaras municipais, tanto dentro ou fora das povoaçōes, sempre que

${ }^{53}$ Decreto de 30 de outubro de 1868. Collecção Official, cit. (n. 16), ano de 1868, pp. 375-376.

${ }^{54}$ Decreto de 11 de dezembro de 1879. Collecção Official, cit. (n. 16), ano de 1879, pp. 267-268.

55 Collecção Official, cit. (n. 16), ano de 1879, pp. 271-273. 
tal matéria estivesse regulada nas posturas, com exceção das cidades de Lisboa e Porto, nas quais vigoravam outras determinações governativas ${ }^{56}$.

A portaria de 13 de dezembro de 1879 estabeleceu ainda que as obras localizadas próximo de lugares fortificados ficavam dependentes do consentimento dado pelo Ministério dos Negócios da Guerra, cujas indicaçōes acompanhavam a licença do governo. Semelhante necessidade acontecia em relação às obras nas orlas dos rios navegáveis, mas agora relativamente ao Ministério da Marinha e Ultramar, algo que, aliás, já tinha sido regulado pelo decreto de 17 de outubro de 1865 , pelo qual se tinha proibido a edificação, exploração de pedreiras, aterros ou desaterros nas margens dos rios navegáveis e nas costas do mar (até ao limite da praia-mar durante as águas-vivas), sem licença do governo dada por este Ministério ${ }^{57}$.

Mas em 1881, uma portaria procurava esclarecer que a faixa non aedificandi com largura de 2 metros confinante com as estradas reais e distritais impunha-se apenas para as edificações de obras novas, não sendo, portanto, extensiva às reedificações de obras existentes. Neste último caso, não era necessário obter prévia licença do Ministério das Obras Públicas, Comércio e Indústria, devendo apenas os proprietários em causa prevenir as direçôes distritais das Obras Públicas para lhe ser dado o alinhamento e nivelamento e para fiscalizar a observância das leis e regulamentos de polícia e conservação das estradas. Por não ser necessária licença, neste caso não eram devidos emolumentos ${ }^{58}$.

Devido à dispersão e complexificação das disposições legais relativas à construção, conservação, arborização e polícia das estradas, estas acabaram, em 21 de fevereiro de 1889 , por ser compiladas e concentradas num único regulamento, remetendo cada norma para a fonte legal anterior que a tinha instituído ${ }^{59}$. Relativamente às disposiçôes para os proprietários confinantes com as estradas, este regulamento não alterou nenhuma das normas anteriores, acrescentando, porém, novas restrições relativamente às fachadas dos edifícios, algumas das quais já se encontravam discriminadas para Lisboa e Porto $^{60}$. Assim, a altura dos próprios edifícios passava a estar dependente da largura da estrada ou da rua ${ }^{61}$. Além disto, nas frontarias dos pisos térreos que estivessem sobre via pública passava a ser proibido fazer grades com bojos nas janelas; janelas ou portas abrindo para fora; balcôes saindo fora das ombreiras; e candeeiros exteriores a altura inferior a 2,5 metros acima do pavimento da estrada. A armação de toldos para proteção solar era permitida quando a sua largura não excedesse o passeio quando existente,

56 Caso das disposições contidas no decreto com força de lei de 31 de dezembro de 1864 (ver nota 49) e na carta de lei de 2 de julho de 1867 . Collecção Official, cit. (n. 16), ano de 1867 , p. 438.

57 Collecção Official, cit. (n. 16), ano de 1865, pp. 392-393.

58 Portaria de 3 de agosto de 1881. Collecção Official, cit. (n. 16), ano de 1881, p. 199.

59 Decreto de 21 de fevereiro de 1889. Collecção Official, cit. (n. 16), ano de 1889, pp. $122-138$.

${ }^{60} \mathrm{Na}$ carta de lei de 2 de julho de 1867 (ver parte final da nota 56).

${ }^{61}$ Se a largura da rua fosse inferior a 5 metros os edifícios não podiam ir além dos 12 metros de altura; se compreendida entre 5 e 7 metros os edifícios não podiam ser superiores a 15 metros de altura; e além dos 7 metros, os edifícios só podiam chegar aos 20 metros de altura. Já os edifícios construídos para fora do alinhamento viário, não poderiam exceder os 15 metros. 
ou 1,5 metros quando ausente, e a margem inferior da sanefa não poderia estar colocada a uma altura inferior a 2 metros.

Processualmente, o regulamento de 1889 também não alterou a lógica anterior, agravando antes o tipo de documentação a ser entregue pelos proprietários. $\mathrm{O}$ requerimento a entregar na direção das obras públicas tinha agora que ser acompanhado de planta em triplicado, sendo todos os exemplares devidamente selados. Dois exemplares seguiam para o governo, que devolveria um deles com o diploma de concessão de licença. Todas as restantes formalidades e competências continuavam a ser do modo que até então se praticava.

A exigência de os particulares entregarem a planta em triplicado passou também a aplicar-se às obras permanentes que se quisessem fazer nas costas do mar, baías, enseadas e interior dos portos, álveos e leitos dos lagos, lagoas, rios, valas e outras correntes de água navegáveis ou flutuáveis, ou nas suas margens, cômoros, motas, valados, diques e campos marginais, a partir de 19 de dezembro de 1892 . Nestes casos as licenças eram concedidas pelo governo, pelo Ministério das Obras Públicas, Comércio e Indústria, precedendo informação do respetivo diretor da Circunscrição Hidráulica ${ }^{62}$, conforme já acontecia desde o decreto de 2 de outubro de $1886^{63}$. Aliás, pelo decreto de 1 de dezembro de $1887^{64}$, a concessão destas licenças mas para obras provisórias passava a ser competência do diretor da Circunscrição Hidráulica, mas se as obras se localizassem dentro da jurisdição sobre as costas do mar e a parte marítima dos portos, cabia aos Departamentos Marítimos $^{65}$, pertencentes ao Ministério da Marinha e Ultramar, darem as informaçôes prévias sobre o efeito que tais obras pudessem produzir nas costas ou sob o regímen do porto. Naturalmente que para a emissão de todas estas licenças eram cobrados emolumentos.

${ }^{62}$ Estas circunscrições foram estabelecidas pela lei de 6 de março de 1884 que dividiu o país em quatro, conforme as principais bacias hidrográficas do continente (do rio Minho ao rio Douro inclusive, do rio Douro ao rio Lis inclusive, do rio Lis ao rio Tejo inclusive, e do rio Tejo até ao limite sul do reino). Os decretos de 2 de outubro de 1886 regularam a execução desta lei, estabelecendo ainda que as obras do porto de Leixões e da barra do Douro, como também as obras do porto de Lisboa formavam, como até então, direções especiais. No seguimento da reorganização de todos os serviços do Ministério das Obras Públicas, Comércio e Indústria, pelo decreto $8 .^{\circ}$ de 1 de dezembro de 1892 , as quatro circunscrições foram reduzidas a duas (Norte e Sul), que se constituíam como direçôes especiais do serviço externo deste ministério. Colleç̧ão Offcicial, cit. (n. 16), ano de 1884, pp. 50-52; ano de 1886, pp. 716, 720-734; ano de 1892, pp. 977-986.

${ }^{63}$ Ver nota 62.

${ }^{64}$ Collecção Official, cit. (n. 16), ano de 1887, pp. 609-611.

${ }^{65}$ Por decreto de 30 de agosto de 1839 dividiu-se a costa do reino em três divisões marítimas (Norte, Centro e Sul). Porém, os Departamentos Marítimos só foram criados pelo decreto com força de lei de 22 de outubro de 1851 e definidos pelo decreto de 25 de agosto de 1859, em quatro (Norte, Centro, Sul e Ilhas). Pela lei de 27 de julho de 1882 estas entidades foram reduzidas a três (Norte, Centro e Sul), ficando apenas capitanias e delegaçôes nas ilhas adjacentes. Esta organização foi mantida no decreto de 1 de dezembro de 1892. Depois, o decreto de 18 de abril de 1895 voltou a criar um Departamento Marítimo para as ilhas adjacentes. Collecção de Leis, cit. (n. 6), ano de 1839, pp. 451-460; Colleç̧ão Official, cit. (n. 16), ano de 1851, pp. 385-389; ano de 1859, pp. 487-497; ano de 1882, pp. 258-260; ano de 1892, pp. 1008-1016; ano de 1895 , pp. 425-431. 
Além disso, o decreto de 1 de dezembro de 1892, que organizou os serviços das Circunscrições Hidráulicas, definiu também os limites do domínio público nas margens dos vários tipos de águas públicas, podendo os respetivos proprietários sofrer, nos termos legais, expropriações ou servidōes por utilidade pública. Assim as margens das águas navegáveis e flutuáveis contavam-se da linha do leito ou álveo, geralmente 3 a 30 metros e excecionalmente 50 metros; e as das águas não navegáveis, nem flutuáveis de uso comum contavam-se da linha do leito ou álveo 1 a 3 metros, ainda que estas pudessem ser suprimidas nas lagoas e correntes de águas de menor importância "atendendo ao seu uso, antigos costumes e regimentos"

Já o diploma regulamentar de 19 de dezembro de 1892 estabeleceu também preceitos para próprias peças desenhadas a apresentar: as plantas tinham de ser apresentadas a uma escala nunca inferior a 1/1000; tinham de incluir todos os detalhes convenientes, bem como, alçados, perfis e cortes, considerados necessários para fazer conhecer e apreciar a obra a executar; tinham de abranger de parte do curso de água a montante e a jusante do local onde se pretendia construir, de modo a se poder percecionar o efeito da obra; e tinham ainda que designar o distrito, o concelho, a freguesia e o lugar a que pertencesse; bem como incluir a assinatura pelo requerente e o selo em um dos exemplares. Também estas licenças pagavam emolumentos ${ }^{67}$.

Mas foi com a aprovação, em 1895, do regulamento para o serviço de inspeção e vigilância para a segurança dos operários que trabalhavam na construção civil ${ }^{68}$, que todas as obras de construção -excetuando as obras ordenadas pelo governo e cujo projeto tivesse sido aprovado pelo Ministério das Obras Públicas, Comércio e Indústria-, não mais poderiam começar sem que o respetivo projeto (apresentado através de plantas, cortes e alçados) tivesse sido examinado e aprovado pela Direção distrital das Obras Públicas. Nas obras localizadas dentro dos limites das cidades de Lisboa e Porto as entidades competentes eram as câmaras municipais, ouvidas as suas Repartições Técnicas ${ }^{69}$.

Esta nova exigência não alterava, contudo, as faculdades das câmaras municipais sobre as obras particulares nas ruas e estradas municipais, nem dispensava as formalidades exigidas para as obras que decorressem sobre alçada das Direçóes distritais das Obras Públicas. Esta exigência provocava, sim, no caso de obras dentro de povoações, a duplicação de entidades a quem os particulares tinham de submeter os pedidos de licença de obras. Porém, para evitar demoras, a Di-

${ }^{66}$ Ver nota 62. Com a República, em 15 de outubro de 1914 (decreto no 952), definiu-se a dimensão de 50 metros para o limite de domínio público da costa (contada da linha do máximo da preia-mar), sob jurisdição do Ministério da Marinha. Depois, em 29 de setembro de 1926 (decreto $n^{\circ} 12445$ ) atualizou-se os limites das margens das correntes de águas sujeitas a domínio público: 50 metros nas águas marinhas, 30 metros nas correntes de águas navegáveis ou flutuáveis, 5 metros nas correntes de águas não navegáveis nem flutuáveis. Diário do Govêrno, Série I (Lisboa, 1910-1976), no 188 (15-10-1914), pp. 979-988; no 224 (8-10-1926), pp. 1493-1496.

67 Collecção Official, cit. (n. 16), ano de 1892, pp. 1190-1225.

68 Este regulamento constituía uma continuação do decreto de 14 de abril de 1891, sobre a regulação do trabalho das mulheres e dos menores. Collecção Official, cit. (n. 16), ano de 1891, pp. 135-141.

${ }^{69}$ Decreto de 6 de junho de 1895. Collecção Official, cit. (n. 16), ano de 1896, pp. 541-546. 
reção distrital das Obras Públicas dispunha apenas de 30 dias, contados desde a apresentação do pedido, para aprovar os projetos ou indicar as alteraçôes a serem feitas. A modificação do projeto em fase de obra obrigava a uma nova submissão do projeto de alterações e, tal como o projeto original, as peças eram apresentadas em duplicado, estando todas elas devidamente seladas. Antes de a obra ser começada, tornava-se também obrigatório comunicar o seu início ao responsável da repartição distrital, o qual passava um recibo para poder exercer a devida fiscalização.

Este regulamento obrigava ainda que passasse a existir um responsável pelas obras, fosse este engenheiro, arquiteto, condutor (dos quadros técnicos do Ministério das Obras Públicas, Comércio e Indústria, ou diplomado por qualquer escola nacional ou estrangeira) ou mestre-de-obras, desde que habilitado pela Direção distrital das Obras Públicas e pela câmara municipal onde exercesse o ofício ${ }^{70}$. Além disso, nenhum projeto podia ser aprovado sem que fosse acompanhado de declaração escrita do técnico que assumia a responsabilidade da direção da obra, o qual seria responsável, nos termos do Código Civil, pelos acidentes dos operários, quando estes proviessem da má direção do trabalho, do emprego de material impróprio ou defeituoso e da negligência, imperícia ou inexecução de ordens dadas por parte dos encarregados. Não tendo ainda decorrido um ano sobre a promulgação deste regulamento, uma portaria veio esclarecer as dúvidas suscitadas relativamente às obras de pequena reparação e conservação dos prédios urbanos. Dada a pequena dimensão destas obras, a declaração do técnico habilitado podia ser substituída por uma declaração escrita, devidamente reconhecida, do proprietário ou do seu representante legal, onde este assumia a responsabilidade da direção da obra ${ }^{71}$.

\section{Da descentralização administrativa e da simplificação de alguns procedimentos burocráticos}

No final do século XIX, licenciar uma obra particular em terrenos contíguos aos bens nacionais tornou-se numa tarefa profundamente complexa, não só pelas diversas entidades estatais a quem se tinha de submeter os requerimentos, mas também pelas exigências processuais que incluíam um número cada vez maior de peças desenhadas. Naturalmente sobre estes preceitos recaiam constantes reclamações, com objetivo de descentralizar e simplificar os procedimentos e formalidades da polícia dos bens nacionais.

Em 1896, o deputado Manuel Pedro Guedes propôs a modificação do regime policial dos decretos de 1 e 19 de dezembro de 1892. A razão assentava nas

${ }^{70}$ Esta habilitação era atestada por diploma, o qual podia ser substituído para aqueles que até, à data da promulgação deste regulamento, tivessem completado dez anos de exercício de profissão, comprovado por atestado passado por associação de classe ou por três engenheiros com quem tivessem trabalhado e mostrado provas de competência. Caso contrário, o técnico para obter a habilitação tinha de submeter-se a um exame especial, cujo júri era composto pelo diretor das obras públicas, que presidia, por dois engenheiros-chefes das câmaras municipais e por dois vogais nomeados pelo presidente do júri, escolhidos um entre os funcionários técnicos da direção das Obras Públicas e o outro entre os mestres e obras já habilitados.

${ }^{71}$ Portaria de 28 de junho de 1897 . Collecção Official, cit. (n. 16), ano de 1897, pp. 217-218. 
"disposiçôes vexatorias ali contidas", dados os custos das formalidades e outras exigências impostas pelas Direçôes das Obras Hidráulicas aos proprietários, sobretudo de terrenos confinantes com águas não navegáveis ou não flutuáveis, pois nestas, ao contrário do que acontecia com as águas navegáveis e flutuáveis, não era necessário salvaguardar os interesses do comércio e da navegação. Além disso, o deputado alertava também para o facto de que os proprietários deixavam de fazer obras de conservação e limpeza do leito das correntes, contrariando os potenciais "resultados beneficos que se esperavam"72. Esta proposta foi admitida, mas não chegou a surtir nenhum efeito.

Em 7 de agosto de 1897 a câmara da Lousada fez chegar ao parlamento uma representação sobre o mesmo assunto, relatando os abusos cometidos pelos empregados dos serviços hidráulicos, mas também as dificuldades e prejuízos dos proprietários, causados pela exigência da planta que acompanhava o requerimento, pois era "necessario arranjar artistas competentes que se entendam com a planta levantada por engenheiros, o que é difficilimo nas aldeias; depois a obra quasi sempre fica muito dispendiosa, porque a nossa engenharia propende sempre para o grande e para o espectaculoso, sem se lembrar das precárias circumstancias dos agricultores, que têem de executar á sua custa o projeto"73.

No início do ano seguinte, o par do reino Manuel Vaz Preto Geraldes questionou o ministro das Obras Públicas sobre o mesmo assunto, num violento discurso, manifestando-se contra o próprio decreto -considerando-o como letra morta porque a classificação das bacias hidrográficas não tinha sido cumprida, nem posta à execução-, contra o respetivo regulamento e contra os serviços hidráulicos, por causa dos "actos vexatorios, arbitrarios e despoticos para com os proprietarios" 74 .

De tudo isto resultou a consequente alteração legislativa. Assim, em 1898, as obras simples de reconstrução (sem alteração da disposição ou dimensão) e reparações de construções existentes localizadas nas margens de correntes de águas navegáveis ou não, flutuáveis ou não, bem como para assentamento de máquinas para uso industrial ou agrícola com utilização temporária, foram bastante desoneradas do ponto de vista processual. Deixou de ser preciso solicitar prévia licença ao Ministério das Obras Públicas, Comércio e Indústria, bastando os proprietários prevenir a respetiva Circunscrição Hidráulica, que fiscalizaria a observância das leis e regulamentos. Ao dispensar de licença, estas obras ficavam também dispensadas de pagar os emolumentos ${ }^{75}$.

Mas a alteração legislativa afetou também os próprios serviços hidráulicos limitando igualmente a sua ação. Enquanto não fossem demarcadas e classificadas as bacias hidrográficas, os diretores distritais das Obras Públicas e os chefes dos serviços hidráulicos não podiam exigir aos particulares o procedimento de

72 Diario da Camara dos Senhores Deputados da Nação Portuguesa (Lisboa, 1826-1926), sessão de 8 de maio de 1896 (n.o 74), pp. 1676-1677.

73 Diario do Governo (Lisboa, 1869-1913), n.o 197 (3-9-1897), p. 2413.

74 Diario da Camara dos Dignos Pares do Reino (Lisboa: 1869-1902), sessão de 11 de março de 1898 (n. $\left.{ }^{\circ} 14\right)$, pp. 117-122.

75 Portaria de 31 de março e de 15 de setembro de 1898. Collecção Official, cit. (n. 16), ano de 1898, pp. 91 e 674 . 
licenciar plantações ou construções nas margens das correntes não navegáveis nem flutuáveis, cabendo-lhes apenas a polícia e conservação dos leitos das águas. Foram também dispensadas a apresentação das plantas parcelares nas obras urgentes, temporárias ou provisórias, devendo o chefe de serviço mandar levantar as peças desenhadas pelos empregados do serviço quando achasse necessário ${ }^{76}$. Já para a apresentação das plantas, no caso de obras permanentes, os proprietários passavam a poder requisitar o serviço técnico das Obras Públicas ou das Circunscrições Hidráulicas, não pagando ao empregado respetivo, mas apenas os salários do pessoal jornaleiro que o auxiliavam ${ }^{77}$.

Semelhante alteração processual tinha sido, dias antes, implementada nas licenças para construções ou reconstruçôes de obras de natureza agrícola (como muros de vedação, muros de suporte, vedação de arame em esteios de pedra ou de madeira, encanamentos de água de rega, edificaçōes de casas destinadas à agricultura, habitaçôes rurais e plantaçōes de arvoredo), confinantes com estradas ou caminho-de-ferro. Dois níveis justificavam-na. Por um lado, as formalidades burocráticas, que por sua vez exigiam a satisfação de preceitos técnicos exigidos pelo decreto de 21 de fevereiro de 1889 -como a apresentação de peças desenhadas em triplicado-, representavam um grave entrave aos proprietários-agricultores, fazendo-os adiar a realização de melhoramentos nas suas explorações agrícolas. Por outro, estes processos embaraçavam e atrasavam o expediente do Ministério das Obras Públicas, Comércio e Indústria, sem daí sair vantagem para o serviço público. Por isso, as licenças destas obras passavam a ser solicitadas para o serviço responsável (Direção distrital das Obras Públicas, Direção do caminho-de-ferro, ou Direção da fiscalização das linhas férreas) apenas por meio de requerimento, onde se indicava o local e a natureza da obra. Com o pedido, o respetivo diretor enviava um delegado que ouviria o interessado e levantaria a planta do espaço pretendido, caso achasse conveniente ou necessário. Informado pelo delegado, o diretor fixava os alinhamentos e as condiçôes das obras, mandando fiscalizá-las até à sua conclusão. Desta forma os agricultores ficavam dispensados da apresentação das peças desenhadas. Além do mais, se no prazo de 30 dias depois de requerida a licença, não saísse resolução do diretor do serviço, o requerimento seria deferido tacitamente ${ }^{78}$.

Paralelamente, também se multiplicavam as queixas dos proprietários de prédios confinantes com as estradas, contra a morosidade dos processos burocrá-

${ }^{76}$ De facto, a produção e custo das peças desenhadas sempre constitui um grave problema para os proprietários cumprirem as determinações administrativas. Também esta exigência foi alvo de críticas no licenciamento dos estabelecimentos industriais, determinado pelo decreto de 27 de agosto de 1855, que estabeleceu a primeira obrigatoriedade administrativa em Portugal da apresentação da planta do edifício. Collecção Official, cit. (n. 16), ano de 1855, pp. 294-303. Sobre este assunto ver PINTo, Sandra M. G., O licenciamento dos estabelecimentos insalubres, incómodos ou perigosos no século XIX e as plantas dos processos do distrito de Coimbra, em Boletim do Arquivo da Universidade de Coimbra, 31/1 (2018), pp. 125-162.

77 Decreto de 24 de setembro de 1898. Collecção Official, cit. (n. 16), ano de 1898, pp. 685-689.

78 Decreto de 10 de setembro de 1898. Collecção Official, cit. (n. 16), ano de 1898, pp. 672-673. 
ticos e contra as despesas tidas na concessão das licenças. Para dar resposta a estas reclamações, fundadas "na rasão e na justiça", e atendendo a que as formalidades burocráticas não se podiam transformar "inutilmente em obices ou estorvos para $o$ exercicio dos direitos dos cidadãos, ou para o desenvolvimento material do paiz", o governo procurou simplificar os serviços públicos e, ao mesmo tempo, harmonizar e conciliar os interesses particulares com os do estado, "aliviando os cidadãos de dispêndios escusados e de morosidades, que mal se podem justificar, mormente, quando d'ellas resultem prejuizos materaes e incommodos moraes".

Através do decreto de 20 de outubro de 1898 alterou-se o regulamento de conservação de estradas de 21 de fevereiro de 1889. A partir de então, os pedidos de licença de construção ou plantaçōes junto às estradas reais e distritais deixavam de subir para o Ministério, sendo concedidos diretamente pelos diretores distritais das Obras Públicas e dos chefes de zona dos serviços de Obras Públicas no distrito de Lisboa. Apenas eram enviados para o diretor-geral das Obras Públicas os recursos às denegações das licenças e os pedidos de licença que oferecessem dúvida, que todavia tinham de ser remetidos no máximo em 15 dias. Também passava a haver prazos certos para a concessão das licenças: um mês pelas direções distritais e três meses pelo Ministério; caso contrário, o pedido seria considerado deferido. Além disso, os pedidos de licença podiam agora ser entregues aos chefes de conservação das estradas, dentro da secção onde os trabalhos iam ser executados. E, tal como já tinha sido determinado para os proprietários confinantes com as correntes de águas e para os agricultores, também para os restantes proprietários confinantes com as estradas, bastava-lhes entregar o requerimento em papel selado, com a indicação da natureza da obra ou plantação e o local, competindo aos diretores distritais das Obras Públicas mandar levantar, sempre que julgassem necessário, as plantas dos respetivos terrenos nas quais, em conformidade com as indicaçōes fornecidas pelos proprietários, seriam desenhadas as obras, marcados os lugares escolhidos para a plantação das árvores ou designadas as que se pretendessem cortar. Para o efeito destas, os proprietários não pagavam o serviço do empregado das Obras Públicas mas apenas os salários do pessoal jornaleiro que o auxiliavam. Com a comunicação da concessão da licença seguia a guia para pagamento dos emolumentos legais. Em tudo o mais, seguia-se o estabelecido no regulamento anterior ${ }^{79}$.

No mesmo dia, foram também aprovadas várias modificaçōes sobre o serviço de vigilância e segurança dos operários nas construçôes civis estabelecido pelo decreto de 6 de junho de 1895, fundamentado no mesmo motivo: a dificuldade que os proprietários tinham em cumprir a lei, dada a "absoluta carência de pessoal devidamente habilitado" que soubesse elaborar projetos e que pudesse assumir a direção e responsabilidade pelas obras. As alterações vieram, pois, a simplificar parte dos procedimentos, mas apenas para as obras que se construíssem fora das cidades de Lisboa e Porto.

Com efeito, os mestres-de-obra de Vila Nova de Gaia tinham, em 22 de julho de 1897, enviado uma representação para os deputados, propondo a reforma e

${ }^{79}$ Decreto de 20 de outubro de 1898. Colleç̧ão Offcial, cit. (n. 16), ano de 1898, pp. 742-744. 
eliminação de certos preceitos deste decreto. Afirmavam que no seu concelho as construçōes eram de pequena dimensão e que por isso obrigar os proprietários a contratar um engenheiro, um arquiteto ou um condutor dos quadros dos serviços das Obras Públicas era obrigá-los "a uma avultada despeza, porque nenhum individuo n'aquellas condiçôes vae tomar a responsabilidade de uma obra alheia, senão pagando-lhe generosamente, e casos ha de haver em que o valor da construção ha de ser inferior á quantia que um d'esses indivíduos exigir para tomar responsabilidade". Criticavam, ainda, a obrigatoriedade de ser apresentado um projeto para ser aprovado pela Direção distrital das Obras Públicas, nas obras que decorressem à face das estradas municipais e caminhos vicinais -onde, por tradição, competia às câmaras municipais a decisão-, mas também nas obras interiores, novamente porque "as construcçôes são de pequeno dispendio por pertencerem a gente de poucos meios de fortuna, se ficar obrigada a cumprir com todas as formalidades [...] tem de fazer maior despeza com o cumprimento d'ellas, do que importa o custo da obra" ${ }^{80}$.

Contra esta representação manifestaram-se a associação dos construtores civis e mestres-de-obra de Lisboa e os operários construtores civis do Porto. Os primeiros, que por serem diplomados e por isso poderem dirigir as obras, opunham-se que esta competência voltasse para a "direcção de incompetentes", mas também, que os construtores ou proprietários pudessem alterar os projetos, pois "a mudança das divisóes de uma casa póde influir desastrosamente na sua segurança, na disposição da sua luz e ventilação e consequentemente nas suas condiçôes hygienicas". Já os segundos procuravam manter a unidade regulamentar procurando zelar pela segurança dos próprios operários ${ }^{81}$.

Das alteraçôes introduzidas pelo governo ao decreto de 1895 salientam-se as seguintes. Se as obras fossem empreendidas por corporaçóes administrativas, empresas ou particulares, ficava dispensada a apresentação do projeto na respetiva Direção distrital das Obras Públicas, bastando participá-las com antecedência, esclarecendo o local e o dia do início das obras. Mantinha-se a obrigatoriedade da responsabilização técnica pelas obras, porém, os particulares que desejassem empreendê-las podiam assumir a direção e a responsabilidade das construções, devendo enviar à respetiva Direção distrital das Obras Públicas uma declaração escrita nesse sentido. As participações e as declaraçôes referidas podiam agora ser submetidas na autoridade administrativa da localidade, que ficavam incumbidas de remeter com urgência à respetiva direção das Obras Públicas, poupando assim a deslocação dos particulares, e as assinaturas podiam ser reconhecidas por tabelião ou autenticadas pela mesma autoridade administrativa da localidade ${ }^{82}$.

Dadas as novas disposições para a conservação, arborização e polícia das estradas, em 19 de setembro de 1900 foi publicado um novo regulamento (substituindo a vigência do decreto de 21 de fevereiro de 1889), coligindo novamente num mesmo documento as inovações e as correçōes aos defeitos apontados pela prática

${ }^{80}$ Diario do Governo, cit. (n. 73), n.o 171 (4-8-1897), pp. 2134-2135.

${ }^{81}$ Diario do Governo, cit. (n. 73), n.o 179 (13-8-1897), pp. 2223-2224; n.o 199 (6-91897), p. 2434.

${ }^{82}$ Decreto de 20 de outubro de 1898. Collecção Official, cit. (n. 16), ano de 1898, pp. 745-747. 
que foram introduzidas sobre esta matéria na legislação do reino. Destaque-se algumas das diferenças mais assinaláveis. Passava agora a ser incumbência dos chefes dos serviços de conservação das estradas dar aos proprietários as explicações necessárias em relação às edificaçôes e plantaçôes que se fizessem junto às estradas, bem como no que dissesse respeito à polícia das estradas, fazendo cumprir as condições estabelecidas nas licenças, marcando alinhamentos e nivelamentos. Continuava na competência dos diretores distritais das Obras Públicas mandar levantar, se necessário, a planta do terreno, esclarecendo-se, no entanto, que esta disposição não dispensava o proprietário de apresentar em triplicado o projeto da construção sempre que este carecesse de aprovação. Mas, acrescentava-se ainda uma nova restrição: nos prédios construídos ou naqueles que se fizessem grandes reparaçôes, as águas pluviais tinham de ser recolhidas por algerozes ou calhas nos telhados, conduzidas depois até à via pública e sempre que existissem passeios, a canalização deveria ser prolongada por debaixo destes até à valeta ${ }^{83}$.

\section{DAS SERVIDŌES MILITARES}

Como se disse, a portaria de 13 de dezembro de 1879 estabeleceu que obras localizadas próximo de lugares fortificados ficavam dependentes do consentimento dado pelo Ministério da Guerra. A razão devia-se à existência de servidóes militares.

Ainda que sem esta denominação, a verdade é que as servidōes militares já existiam desde longa data. Nas Ordenaçōes Manuelinas estabelecia-se que "toda a pessoa que teuer campo, ou pardieiro a par do muro da Villa, pode-se acostar a elle, $e$ fazer casa sobre elle, porem fica sempre obrigado, se vier guerra, ou cerco, de a derribar, e dar per ella corredoira e seruentia" ${ }^{4}$. Também, D. João V tinha outorgado, nas Ordenanças Militares de 20 de fevereiro de 1708, a proibição de se lavrar, semear e plantar sobre as muralhas dos corpos das praças, fora delas, nas contraescarpas e fossos, permitindo-se tais ações a uma distância de 15 braças (33 metros) contadas a partir das estradas exteriores ${ }^{85}$; disposição reafirmada pela resolução de 4 de julho de 1754. Em 12 de fevereiro de 1812, pelo regulamento provisional do real corpo de engenheiros, aquela proibição foi alargada à edificaçãao de casas, levantamento de muros, valados, valas, caminhos cobertos e outras construçóes semelhantes numa extensão de 600 braças (1320 metros) contadas a partir da explanada das praças de guerra ou fortalezas; disposição novamente confirmada pela portaria de 17 de maio de $1865^{86}$.

Ora, no final do século XIX, as servidões militares eram impostas aos terrenos

${ }^{83}$ Decreto de 19 de setembro de 1900. Meses antes, por decreto de 5 de abril de 1900 , regulou-se o serviço das Inspeções das Obras Públicas (ver nota 33), passando a serem quatro, correspondentes aos distritos de Lisboa, do Norte, do Sul, e das ilhas adjacentes. Collecção Official, cit. (n. 16), ano de 1900, pp. 93-96, 561-582.

${ }^{84}$ Ordenações Manuelinas, cit. (n. 7), I, Tít. XLIV, $\$$ 43, p. 355; disposição mantida nas Ordenações e Leis, cit. (n. 7), I, Tít. LXVIII, $\$ 41$, p. 332.

85 Systema, ou Collecção dos Regimentos Reaes, Tomo V, Compilação por José Roberto Monteiro de Campos Coelho Sousa (Lisboa, 1789), pp. 357-398, em especial p. 375 (\$ 65).

${ }^{86}$ Collecção Official, cit. (n. 16), ano de 1865, pp. 161-162. 
adjacentes às fortificações, mas também aos que circundassem os estabelecimentos militares onde se fabricassem, manipulassem ou guardassem pólvoras ou outros materiais explosivos destinados aos usos militares. Porém, a legislação nacional sobre o assunto era "reconhecidamente defeituosa, por incompleta, desconnexa" e, acima de tudo, desatualizada, tendo a Comissão das Fortificaçōes do Reino ${ }^{87}$ ficado encarregue de formular nova lei. Até sair a nova legislação, o Ministério da Guerra regulou, por decreto de 26 de dezembro de 1893, os serviços das inspeções de engenharia da sua competência ${ }^{88}$, confirmando as normas em vigor, mas facultando agora aos oficiais os meios para exercerem a ação fiscalizadora nas obras próximas a fortificações e edifícios militares ${ }^{89}$.

Assim, os pedidos de licenças de obras localizadas nas áreas de servidão militar eram dirigidos aos governadores das praças de guerra ou aos comandantes militares, que remeteriam o pedido aos inspetores de engenharia na respetiva Divisão Militar territorial ${ }^{90}$, existindo nesta altura quatro destes serviços no continente, um nas ilhas adjacentes, e outro na Inspeção das Fortificações de Lisboa ${ }^{91}$. Os pedidos de licença faziam-se acompanhar dos seguintes documentos: planta do prédio fosse ele rústico ou urbano; certidão da matriz predial e certidão da respetiva descrição e inscrição na conservatória privativa do registo predial. $\mathrm{O}$ inspetor tinha, na resposta ao pedido, que informar precisa e circunstanciadamente a situação do prédio, qual o setor da fortificação e a zona de servidão abrangida pelo prédio, e a distância aos pontos de referência e à fortificação, apreciando ainda, sob o ponto de vista militar, a concessão pedida e as condições a que devia estar submetida. Para a concessão devia-se lavrar escritura pública com eventual obrigação de demolição em caso de guerra ou em caso de passagem da fortificação ao estado de defesa, não acarretando qualquer indemnização para o proprietário das obras.

Todavia, em 1895 foi publicado o decreto sobre as servições de terrenos adjacentes às praças de guerra e fortificações militares, estabelecendo, pois, “ $o$ direito que o estado tem de não permitir construcçôes ou trabalhos que prejudiquem ou diminuam a importância das fortificaçôes" "92. As servidōes militares nos terrenos

${ }^{87}$ Comissão criada pelo decreto de 27 de março de 1893. Collecção Official, cit. (n. 16), ano de 1893, p. 178.

${ }^{88}$ Estes serviços foram estabelecidos na reforma do exército decretada em 30 de outubro de 1884. Collecção Official, cit. (n. 16), ano de 1884, pp. 442-469.

${ }^{89}$ Collecção Official, cit. (n. 16), ano de 1893, pp. 1017-1033.

${ }^{90}$ As divisões-administrativas militares foram criadas pelo decreto de 20 de outubro de 1835 , sendo por esta altura sete. Com a reorganização geral do Exército, pelo decreto de 26 de novembro de 1836 , estabelecem-se dez divisões militares, oito no continente e duas nas ilhas adjacentes. Em 20 de dezembro de 1849, estas divisões foram reduzidas a três, todas no continente (divididas em 8 subdivisões), já que nas ilhas adjacentes havia apenas comandos militares, integrados na primeira divisão. Por decreto de 13 de dezembro de 1869, as divisões administrativas militares passaram a ser cinco, reduzidas pelo decreto de 30 de outubro de 1884 a quatro (todas no continente), havendo novamente apenas comandos militares nas ilhas adjacentes. Collecção de Leis, cit. (n. 6), ano de 1835 pp. 372-373; ano de 1836 (2o sem.), p. 207; Collecção Official, cit. (n. 16), ano de 1849, pp. 451-487; ano 1869, pp. 728-730.

91 Inspeção criada pelo decreto de 27 de março de 1893 (ver nota 87).

${ }^{92}$ Decreto n.o 9 de 10 de janeiro de 1895. Collecção Official, cit. (n. 16), ano de 1895, pp. 62-69. 
circundantes às fortificações passaram a ser divididas em três zonas distinguidas pela sua proximidade. Assim, a primeira zona compreendia a área definida pelo perímetro exterior da explanada da fortificação até à distância de 600 metros da crista da explanada; a segunda zona, desde a primeira zona até à distância de 1000 metros da crista da explanada (ou 400 metros desde a primeira zona); e a terceira zona, desde a segunda zona até à distância de 3000 metros da crista da explanada (ou 2000 metros desde a segunda zona). Na primeira zona era proibido construir acima ou abaixo do solo, e as próprias divisórias de propriedade só podiam ser estabelecidas a uma distância mínima de 300 metros da crista da explanada. $\mathrm{Na}$ segunda zona era também proibido construir abaixo do solo, sendo que acima do solo as construçôes de paredes de alvenaria, taipa ou adobes não podiam ter espessura superior a 30 centímetros, não podiam ter socos ou lareiras de alvenaria acima dos 30 centímetros, nem ser abobadadas, as quais ficavam dependente de licença prévia. Na terceira zona ficavam também dependentes de licença prévia: qualquer obra pública de viação (estradas ou caminho-de-ferro); construções em altura (com exceção das chaminés) que pudessem devassar o inferior da fortificação a menos de 2000 metros da crista da esplanada; e construçôes que pudessem oferecer abrigo ao atacante ou ocultar a visibilidade da própria fortificação.

Foram também definidas três zonas circundantes às fábricas e depósitos de pólvoras e outros explosivos de guerra. Assim, a primeira zona era limitada pelo muro ou vedação destas construções até à distância de 25 metros; a segunda zona limitada pela primeira zona até à distância de 50 metros do muro ou vedação (ou 25 metros da primeira zona); e a terceira zona limitada pela segunda zona até à distância de 500 metros do muro ou vedação (ou 450 metros da segunda zona). E, semelhantemente, era também proibido construir acima ou abaixo do solo nesta primeira zona; era proibido construir com materiais incendiáveis e estabelecer fábricas ou depósitos de substâncias explosivas ou inflamáveis na segunda zona, necessitando-se de licença prévia para os restantes casos; enquanto na terceira zona apenas as fábricas ou depósitos de substâncias explosivas ou inflamáveis ficavam interditas, ainda que para os restantes casos fosse necessário solicitar licença prévia.

Todas estas zonas de servidóes militares criavam-se automaticamente sempre que se estabelecem novas fortificações, enquanto para as existentes a sua delimitação seria fixada por decretos especiais. As construções existentes dentro dessas áreas ficavam, então, subordinadas e dependentes de licença prévia para as ações de conservação, reconstrução e ampliação.

A portaria de 5 de abril de 1898 veio, finalmente, definir os documentos que deviam acompanhar os requerimentos para as obras particulares nas zonas de servidão militar. Assim, além da planta geral em escala não inferior a 1/1000 metros, indicando a situação da obra em relação ao seu prédio e prédios vizinhos, das informaçōes topográficas (concelho, freguesia, lugar e direção do meridiano magnético), e das certidôes da matriz e registo predial até então exigidos, passou a ser obrigatório a apresentação da planta e alçado da construção, em escala não inferior a $1 / 200$, indicando ainda a natureza dos materiais de construção, a espessura das paredes, a altura dos socos de alvenaria quando existentes, e a altura do espigão da cobertura. Também estas peças desenhadas eram entregues em 
triplicado, uma delas em papel tela, todas com selo, sendo somente dispensável a planta geral para a construçóes de valados, valsas, sebes ou gradeamentos de madeira, e/ou a planta e alçado do edifício na terceira zona (com exceção de áreas reservadas dentro dessas). Justificam-se estas exigências processuais pela necessidade dos inspetores de engenharia avaliarem competentemente e conforme as limitaçôes impostas pela lei os requerimentos dos particulares. De igual modo, no caso das obras públicas, tornava-se obrigatório a apresentação dos respetivos projetos, quer as peças escritas e desenhadas, na parte em que cruzavam com as zonas de servidão militar ${ }^{93}$.

Naturalmente todas estas exigências processuais provocaram inúmeras reaçōes, sobretudo numa altura em que se simplificava os procedimentos relativos às obras dos particulares em terrenos contíguos aos bens nacionais civis. Daí que em 20 de março de 1902 o deputado José Dias Ferreira, na Câmara dos Deputados, questionou o ministro da Guerra, Luís Augusto Pimentel Pinto, sobre estes decretos. Em causa, dizia, já nem estava o direito de propriedade, mas o que considerava como "os onerosos vexames" a que estavam sujeitos os proprietários para empreenderem uma qualquer ou simples construção. Por um lado, considerava excessivo o limite de 3000 metros adjacentes às fortificações para servidão militar, onde ninguém podia na sua propriedade, construir "uma pequena casa para um cão de guarda, ou para recolher gallinhas, sem licença do Ministério da Guerra”. Por outro, afirmava que "mais vexatorio que a licença são as exigências para a concessão da licença". De facto, segundo ele, para a constituição do complexo processo, torna-se necessária a intervenção de um advogado ou solicitador tais eram as informações e certidóes requeridas, algumas das quais inúteis do ponto de vista militar, para além da própria produção e número de peças desenhadas a entregar. Tudo isto obrigava os proprietários a despenderem de elevadas quantias e a perderem meses e/ou anos só em procedimentos burocráticos. $\mathrm{O}$ deputado apelava então ao ministro que tivesse "disposto a ter caridade com o proprietário, e a alliviá-lo de encargos que teem tanto de vexatório para o contribuinte, como de inuteis para o Estado" ${ }^{4}$.

$\mathrm{O}$ ministro atestou que a lei da servidão militar era "realmente muitissimo rigorosa e muitissimo exigente", mas que os rigores e exigências eram muitos inferiores, quase metade, dos da lei alemã que lhe serviu de base. Porém, dada a sua severidade, alertava que tinha apresentado no ano anterior e no ano corrente, propostas de modificação e melhoramento ${ }^{95}$. A lei de 24 de maio de 1902 veio, de facto, substituir o decreto de 10 de janeiro de 1895, mas a verdade é que nas normas contestadas por Dias Ferreira não se registaram substanciais alteraçōes, acrescentando-se antes outras disposições sobre estruturas que até então não tinham sido consideradas, caso as fortificações marítimas ${ }^{96}$.

\footnotetext{
93 Collecção Official, cit. (n. 16), ano de 1898, pp. 93-94.

${ }^{4}$ Diario da Camara, cit. (n. 72), sessão de 20 de março de 1902 (n. ${ }^{\circ} 41$ ), pp. 11, 15-16.

${ }^{5}$ Diario da Camara, cit. (n. 72), sessão de 20 de março de 1902 (n.o 41), pp. 11-12.

${ }^{96}$ Collecção Official, cit. (n. 16), ano de 1902, pp. 187-193.
} 


\section{DAS LIMITAÇÕES DA PROPRIEDADE PRIVADA PARA UTILIDADE PÚBLICA}

A Constituição Portuguesa de 1822 estabelecia no seu artigo 6.": "A propriedade é um direito sagrado e inviolável, que tem qualquer Portuguez, de dispôr á sua vontade de todos os seus bens, segundo as leis. Quando por alguma razão de necessidade publica e urgente, for preciso que elle seja privado deste direito, será primeiramente indemnisado, na forma que as leis estabelecerem"97. A Carta Constitucional de 1826 estabelecia no seu artigo 145..$^{\circ}$ \$21: “He garantido o Direito de Propriedade em toda a sua plenitude. Se o bem Publico, legalmente verificado, exigir o uso, e emprego da propriedade do Cidadão, será elle previamente indemnisado do valor d'ella. A lei marcará os casos, em que terá lugar esta única excepção, e dará as regras para se determinar a indemnização" "98. A Constituição Politica de 1838 estabelecia no seu Título III (Dos direitos e garantidas dos portugueses), artigo 23. ': "É garantido o direito de propriedade. Com tudo, se o bem publico, legalmente verificado, exigir o emprego ou damnificação de qualquer propriedade, será o proprietário préviamente indemnizado. Nos casos de extrema e urgente necessidade, poderá o proprietário ser indemnizado depois da expropriação ou damnificação"'99.

Ainda que a efetiva vigência destes diplomas não tenha correspondido à ordem da sua produção ${ }^{100}$, a sua ordenação demonstra bem como, em poucos anos, o direito de propriedade particular, inicialmente entendido como a faculdade de se usar e dispor livremente os bens, motivado pela proeminência das liberdades e dos direitos individuais ${ }^{101}$, começou a ser refreado pelo bem público.

Também o Código Civil definiu como limites ao direito de propriedade e aos direitos por ele abrangidos a "natureza das cousas", a "vontade do proprietário", e a "disposição expressa da lei"102, significando que bastava o enquadramento legal, através de disposições legislativas e/ou regulamentares do direito administrativo, para a propriedade particular passar a estar limitada e conformada ao interesse público. À expropriação, que constituía originalmente a única exceção constitucional ao direito de propriedade -exceção que em todo caso estava coberta pela garantia da indemnização-, acrescentaram-se depois as servidões e as restrições por utilidade pública, na maior parte das vezes sem daí advir qualquer compensação.

Esta alteração ideológica ocorreu, como se viu, na segunda metade do século XIX, quando "a agenda dos administrativistas torna-se mais agressiva", quando

97 Constituição Politica, cit. (n. 8), p. 7.

98 Carta Constitucional, cit. (n. 4), p. 57.

99 Constituição Politica, cit. (n. 9), p. 7.

${ }^{100}$ Muito sinteticamente vigorou a Constituição de 1822 entre 1822 e 1823 e entre 1836 a 1838; a Carta Constitucional de 1826 entre 1826 a 1828, entre 1834 a 1838, e entre 1842 a 1910 com atos adicionais em 1852, 1885 e 1896; e a Constituição de 1838 entre 1838 a 1842. Ver Hespanha, António M., cit. (n. 2), pp. 79-431.

101 Sobre esta visão ver HespanHA, António Manuel, O jurista e o legislador na construção da propriedade burguesa liberal em Portugal, em Análise Social, 16/61-62 (1980), p. 211-236; Cordero Quinzacara, Eduardo; Aldunate Lizana, Eduardo, Evolución histórica del concepto de propriedad, em REHJ, 30 (2008), pp. 378-385.

${ }^{102}$ Codigo Civil Portuguez, cit. (n. 48), art. $2170 .^{\circ}$, p. 356. 
“o conceito de Estado vai-se tornando hegemónico" e quando o interesse individual começa a ser substituído pelo interesse social ${ }^{103}$. Foi, pois, a modernização e a construção de novas infraestruturas de comunicação (rodoviárias, ferroviárias, fluviais, marítimas) do país, a cargo do governo, que deu origem a novas entidades administrativas, a novas limitações e a novas exigências burocráticas sobre a propriedade particular, sobretudo àquela que ficava contígua aos bens nacionais.

Com efeito, inspeções, direções, divisões, circunscrições, departamentos, repartiçōes, passaram a fiscalizar as ações dos proprietários. Espaços vazios, zonas proibidas, áreas non aedificandi, passaram a existir na propriedade particular para benefício público. Requerimentos, informações topográficas, assinaturas, emolumentos, selos, passaram a ser apresentados e custeados pelos particulares. E, acima de tudo, plantas, esse elemento de representação gráfica até então ausente da cultura construtiva portuguesa corrente, e que, de um só ápice utilizando modelos estrangeiros passou a fazer parte da nova cultura administrativa institucional.

Se na segunda década do século XIX as propriedades localizadas fora dos espaços urbanos gozavam de uma quase completa liberdade de edificar, em menos de 50 anos foram-lhes impostas exigências maiores daquelas que recaiam sobre as propriedades urbanas ${ }^{104}$. Daí as reclamações e as resistências populares, mas daí "também a desconfiança e hostilidade geral do pensamento liberal face à crescente intervenção e burocratização do Estado" 105 , onde o constitucional direito de propriedade passava agora para segundo plano face aos prejuízos derivados da excessiva papelada.

As reformas simplificadoras desses mesmos procedimentos demonstram como a realidade estava bastante desfasada das inovações que as normas jurídicas procuravam fomentar. A tão esperada renovação de hábitos e a modernização de comportamentos detinha-se frente a costumes e tradições antigas ${ }^{106}$, mas esbarrava, fundamentalmente, com dificuldades materiais concretas, dada a falta de técnicos especializados que produzissem as peças desenhadas ou que assumissem a responsabilidade das obras, dada a complexa e lenta tramitação dos processos, dados os elevados custos que os proprietários tinham de despender relativamente aos benefícios a auferir, sobretudo fora das grandes cidades.

No início do século XX as limitações ao direito de propriedade impostas pela utilidade pública tornaram-se francamente aceites, pois "não se tratava mais de compatibilizar a acção do Estado com os direitos dos indivíduos; tratava-se, sim, de encontrar novas fórmulas jurídicas compatíveis com esta aparentemente inexorável

103 Hespanha, António M., O direito administrativo como emergência de um governo activo (c. 1880-c. 1910), em Revista de História das Ideias, 26 (2005), pp. 120-121.

${ }^{104}$ E nestas havia já um antigo costume de licenciar as obras particulares, para além de que algumas câmaras facilitavam alguns procedimentos colocando os seus serviços técnicos em prol da população. PinTo, Sandra M. G., cit. (n. 12), pp. 169-170.

105 Almeida, Pedro Tavares de, cit. (n. 30), p. 250.

106 Como aconteceu, por exemplo, com a reforma dos pesos e medidas (ver nota 44), pois "contrariava práticas e tradiçōes culturais profundamente enraizadas". BranCO, Rui Miguel, $A$ introdução do sistema métrico-decimal em Portugal, em Burocracia, Estado e Território, Portugal e Espanha (séculos XIX-XX) (Lisboa, 2007), p. 157. 
ingerência do Estado na sociedade" 107 . Às limitações resultantes da contiguidade às vias de comunicação (com objetivo de assegurar a manutenção dessas estruturas e a fluidez do trânsito), ou resultantes da proximidade às estruturas militares (com objetivo de assegurar a defesa nacional), começaram a surgir muitas outras e com novos objetivos. Por exemplo, no decreto de 30 de dezembro de 1902, pelo qual o Ministério das Obras Públicas, Comércio e Indústria aprovou as bases para a classificação dos monumentos nacionais e bens mobiliários de valor, definiam-se "servidōes, resultantes da classificação", as quais eram inalteráveis e independentes do titular da propriedade ${ }^{108}$. Do mesmo modo, começaram a surgir outras exigências burocráticas. Por exemplo, o Regulamento de Salubridade das Edificaçôes Urbanas de 1903, aumentou as peças desenhadas que acompanhavam os pedidos de licença e exigiu a apresentação de outros esclarecimentos para que uma nova entidade, a Comissão dos Melhoramentos Sanitários, pudesse verificar as prescrições sanitárias. Foi ainda introduzida uma nova formalidade administrativa: nenhuma casa construída de novo ou reconstruída poderia ser habitada sem a câmara municipal passar a respetiva licença de habitabilidade ${ }^{109}$.

Com o tempo, tais limitações, exigências e formalidades não pararam de crescer, e com elas vieram os primeiros estudos sobre administração pública e sobre as limitações da propriedade particular por motivos de utilidade pública ${ }^{110}$. A polícia dos bens nacionais de uso geral e comum, agindo sobre "âmbitos administrativos até aí "vazios»" 111 , deu origem a novos institutos jurídicos, sobre os quais assenta

107 Hespanha, António M., cit. (n. 103), p. 138. Sobre esta nova visão ver sobretudo PEDrosa, A. L. Guimarães, Curso de ciência da administração e direito administrativo, I-Introdução e parte I (Coimbra, 1908).

108 Collecção Official, cit. (n. 16), ano de 1902, pp. 1436-1437. No entanto, estas servidóes só foram definidas em 7 de março de 1932 (decreto n. ${ }^{\circ}$ 20985), quando se estabeleceu que todos os edifícios dentro do raio de 50 metros a contar desde o monumento nacional, não podiam ser alienados, construídos ou modificados sem parecer favorável do Conselho Superior de Belas Artes, e em 18 de novembro do mesmo ano (decreto n. ${ }^{\circ} 21875$ ), estabeleceu-se que esses monumentos nacionais ou outros edifícios públicos de reconhecido valor arquitetónico podiam ter zonas de proteção, nas quais poderiam ser fixadas áreas vedadas à construção, ficando as câmaras municipais impedidas de dar licença para construção ou reconstrução de edifícios particulares sem a prévia aprovação dos respetivos projetos pelo Ministério das Obras Públicas e Comunicações, depois de ouvidas a Direção-Geral dos Edifícios e Monumentos Nacionais, as juntas e comissões administrativas autónomas ou outros organismos do Estado encarregados da construção e conservação de edifícios públicos e, ainda, o Conselho Superior de Belas Artes. Diário do Govêrno, cit. (n. 66), n.o 56 (7-3-1932), pp. 431-436; n.o 271 (18-11-1932), pp. 2237-2238.

109 As quais só podiam ser concedidas depois de passar dois meses no verão e três meses no inverno posteriormente à conclusão dos revestimentos interiores. Decreto de 14 de fevereiro de 1903. Collecção Official, cit. (n. 16), ano de 1903, pp. 66-70.

${ }^{110}$ Em especial, Matta, José Caeiro da, $O$ direito de propriedade e a utilidade pública. Das expropriaçôes (Coimbra, 1906), pp. 56-64; RoDRIGUES JúNIOR, Manuel, Restrições de utilidade pública ao direito de propriedade, em Boletim da Faculdade de Direito (Coimbra), 8/71-80 (19231925), pp. 89-115.

111 Hespanha, António M., Para uma teoria da história institucional do Antigo Regime, em Poder e Instituiçôes na Europa do Antigo Regime: colectânea de textos (Lisboa, 1984), p. 77. 
a atual estrutura contemporânea da propriedade privada e do licenciamento de obras particulares.

\section{BiBLIOGRAFIA}

Almeida, Pedro Tavares de, A construção do Estado Liberal. Elite política e burocracia na 'Regeneração' (1851-1890) (Tese de doutoramento, Universidade Nova de Lisboa, 1995).

Amunátegui Perelló, Carlos Felipe, Las relaciones de vecindad y la teoría de las inmisiones en el Código Civil, em Revista de Derecho de la Pontificia Universidad Católica de Valparaiso, 38/1 (2012), pp. 77-120.

Branco, Rui Miguel C., A introdução do sistema métrico-decimal em Portugal, em Burocracia, Estado e Território, Portugal e Espanha (séculos XIX-XX) (Lisboa, 2007), pp. 137-161.

Caetano, Marcelo, A codificação administrativa em Portugal (um século de experiência 1836-1935), em Revista da Faculdade de Direito da Universidade de Lisboa, 2 (1934), pp. 324-405.

CaEtano, Marcelo, Manual de Direito Administrativo (10. ${ }^{\text {a }}$ ed. revista e atualizada, Coimbra, 1991), 2 vols.

Cordero Quinzacara, Eduardo; Aldunate Lizana, Eduardo, Evolución histórica del concepto de propiedad, em REHJ, 30 (2008), pp. 378-385.

Hespanha, António M., O jurista e o legislador na construção da propriedade burguesa liberal em Portugal, em Análise Social, 16/61-62 (1980), pp. 211-236.

Hespanha, António M., Para uma teoria da história institucional do Antigo Regime, em Poder e Instituiçôes na Europa do Antigo Regime: colectânea de textos (Lisboa, 1984), pp. 7-89.

Hespanha, António M., Guiando a mão invisivel. Direitos, Estado e Lei no Liberalismo Monárquico Português (Coimbra, 2004).

Hespanha, António M., O direito administrativo como emergência de um governo activo (c. 1880-c. 1910), em Revista de História das Ideias, 26 (2005), pp. 119-160.

Manique, António Pedro, Liberalismo e Instituiçôes Municipais, 1822-1910, em 2.o Encontro Nacional de Arquivos Municipais (Montemor-o-Novo, 23-25 de Novembro de 1988): Actas (Lisboa, 1992), pp. 75-100.

Manique, António Pedro, Poder municipal ou poder administrativo? Um conflito entre a Câmara Municipal de Lisboa e o Governo (1834-1835), em Cadernos do Arquivo Municipal (Lisboa), 2 (2014), pp. 243-269.

Matos, Artur Teodoro, Transportes e comunicaçôes em Portugal, Açores e Madeira (17501850), (Ponta Delgada, 1980).

MatTa, José Caeiro da, $O$ direito de propriedade e a utilidade pública. Das expropriaçôes (Coimbra, 1906).

Monteiro, Cláudio, Escrever direito por linhas rectas, Legislação e planeamento urbanistico na Baixa de Lisboa (1755-1833) (Lisboa, 2010).

Monteiro, Cláudio, O domínio da cidade, A propriedade à prova no direito do urbanismo (Tese de doutoramento, Universidade de Lisboa, 2010).

Moreira, Guilherme Alves, As águas no Direito Civil Português, Volume II - Das servidóes das águas (Coimbra, 1922).

Pedrosa, A. L. Guimarães, Curso de ciência da administração e direito administrativo, I- Introdução e parte I (Coimbra, 1908). 
PINTo, Sandra M. G., "Portugal plantou a mais duradoira de suas conquistas». Da antiga tradição jurídica para o construtivo em Portugal e no Brasil: inovação e permanência em perspetiva comparada, em Anais de História de Além-Mar, 16 (2015), pp. 369-405.

PINTO, Sandra M. G., A regulação jurídica das fachadas em Portugal (séc. XIV-XIX), em REHJ., 38 (2016), pp. 149-177.

PINTO, Sandra M. G., O licenciamento dos estabelecimentos insalubres, incómodos ou perigosos no século XIX e as plantas dos processos do distrito de Coimbra, em Boletim do Arquivo da Universidade de Coimbra, 31/1 (2018), pp. 125-162.

Rodrigues JúnIOR, Manuel, Restriçôes de utilidade pública ao direito de propriedade, em Boletim da Faculdade de Direito (Coimbra), 8/71-80 (1923-1925), pp. 89-115.

Serra, José B., As reformas da administração local de 1872 a 1910, em Análise Social, 24/103-104 (1988), pp. 1037-1066.

SiLVEIRA, Luís Nuno Espinha, Território e poder: nas origens do estado contemporâneo em Portugal (Cascais, 1997). 